\title{
تقويم دور أخصائى الإعلام التربوى فى ضوء المعايير القومية لضمان جودة التعليم والإعتماد في لرعاد
}

\author{
دارهام رشدى خير الله \\ مدرس الإعلام بقسم الإعلام التنربوى الفئ \\ كلية النربية النوعية - جامعة المنوفية الاعلامية
}

$$
\begin{aligned}
& \text { أ.د/هناء السيد على محمد } \\
& \text { أستاذ الإعلام المساعد ورئيس قسم آلماء }
\end{aligned}
$$

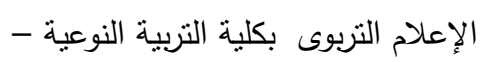

$$
\begin{aligned}
& \text { جامعة الدنوفية }
\end{aligned}
$$

هناء سيد شعبان عبدالله

باحثة ماجستير بقسم الإعلام التربوى كلية التربية

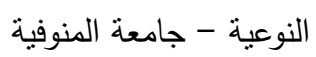

ملخص البحث: - n

استهدف هذا البحث تقويم دور أخصائى الإعلام التربوى فى ضوء المعايير القومية

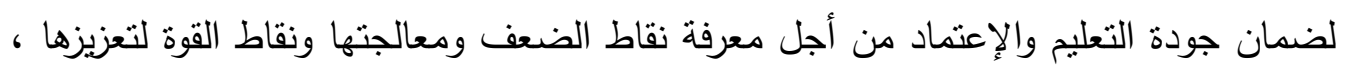
ونم إستخدام المنهج الوصفى لدراسة الواقع وتحديد العوامل المؤثرة فيه والتحليل والتفسير ، واستخدمت الباحثة عينة قوامها ـ . .ـ مفردة من أخصائيين الإعلام التربوى وإستخدمت الباحثة

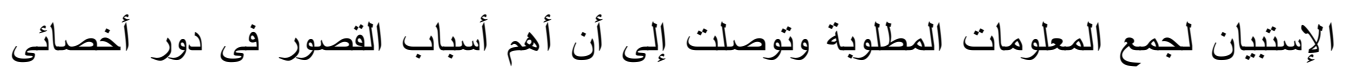

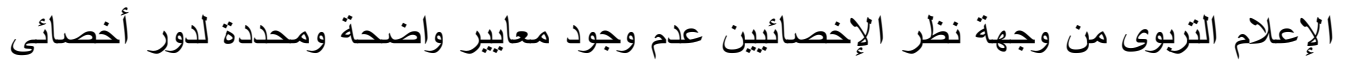
الإعلام التربوى فى المجال المدرسى، حيث جاءت بنسبة بلغت ـ19.0\% من إجمالى مفردات

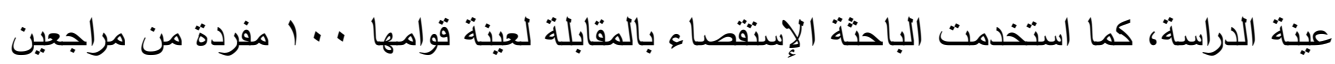

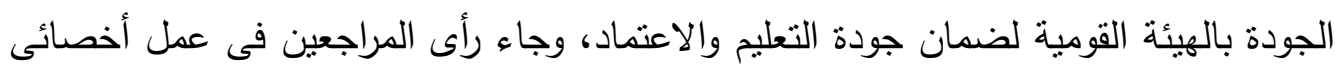

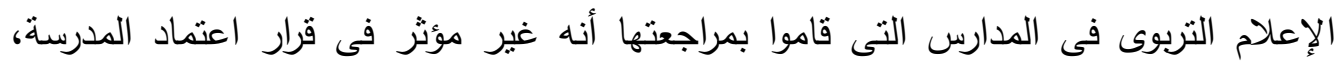
بنسبة بلغت . . . 1 ٪ من إجمالى مفردات عينة مراجعين الجودة .

Targeted this research to evaluatthe role of the educational media specialist in light of the national standards to ensure the quality of education and accreditation in order to identify the weaknesses and their treatment and the strengths to strengthen them. The descriptive approach was used to study the reality and identify the factors influencing it, analysis and interpretation. The researcher used a sample of 400 individuals of educational media specialists The researcher asked the questionnaire to collect the required information and found that the most 
important reasons for the lack of the role of the specialist of educational information from the point of view of specialists, the lack of clear and specific criteria for the role of specialist media education, came at a rate of $89.50 \%$ of the total single And the researcher used the survey to interview a sample of 100 quality reviewers in the National Authority for Quality Assurance of Education and Accreditation. The reviewers of the work of the educational media specialist in the schools that reviewed them found that Was not affected by the decision to approve the school, with $85.00 \%$ of the total sample of the quality reviewers. 
يعد تحديد مشكلة الدراسة وصياغتها فى أسلوب علمى سليم من أهم الخطوات التى تؤثز

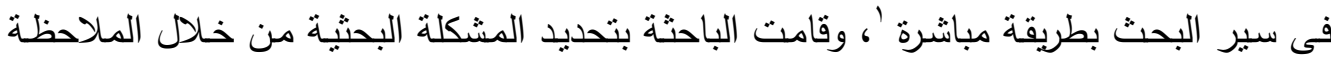

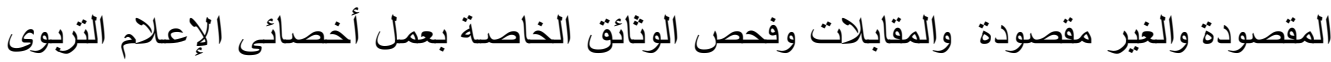
حيث ان الباحثة تعمل أخصائى إعلام تربوى بالتربية والتعليم وقد لاحظت الباحثة أن لممارسة التهاتِ

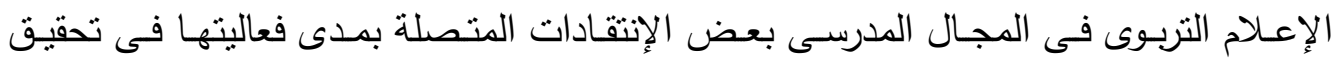

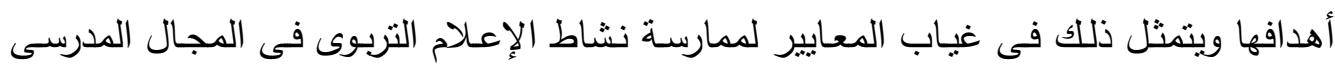

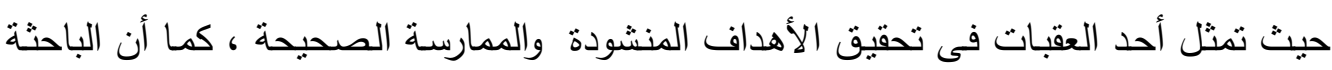
تعمل مراجعا خارجا للجودة بالهيئة القومية لضمان جودة التعليم والإعتماد ، وهذا العمل عبارة

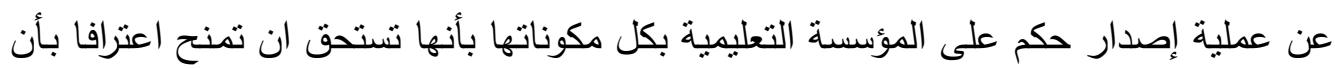

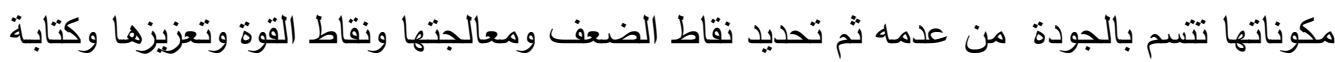
ذلك فى تصور مفترح للمؤسسة التعليمية حتى تتخذه منهاجـا لها لتقدمها، فقكرت الباحثة أن فئن

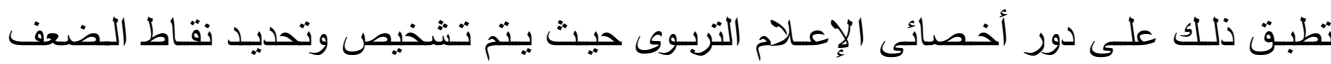

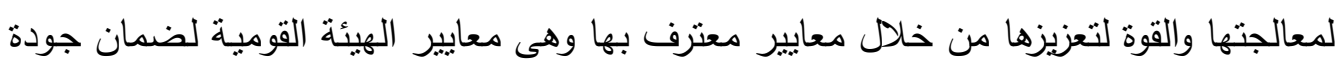

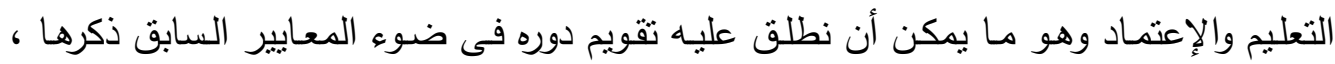
ومن هنا تكمن مشكلة البحث الرئيسية فى الإجابة على السؤال التالى : لإنى

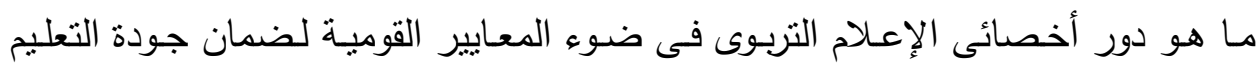
والإعتماد . هدف البحث : يهدف البحث الحالى إلى : تقويم دور أخصائى الإعلام التربوى فى ضوء المعايير القومية لضمان جودة التعليم والإعنماد ويتفرع من هذا الهدف عدة أهداف فرعية وهى :

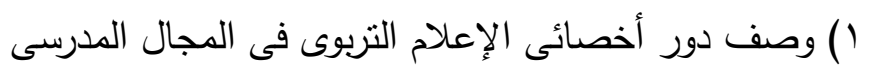

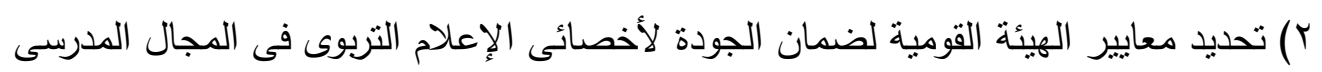

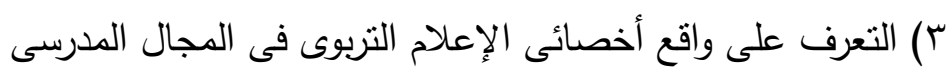

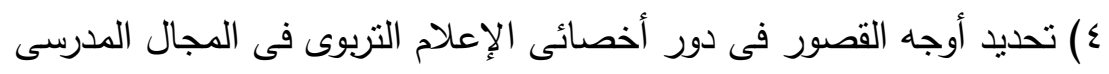

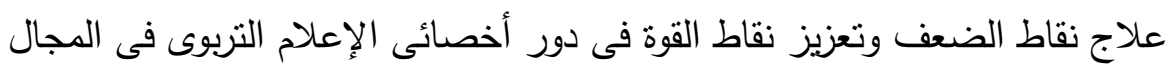




\section{أهمية البحث :

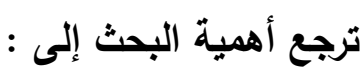

ا-يستمد هذا البحث أهمية من أنه يسعى لسد ثغرة في مجال الإعلام التزبوى المدرسى.

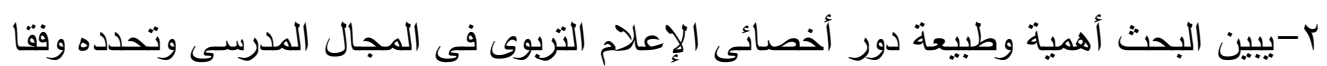

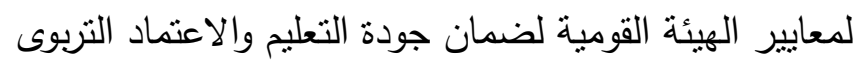
ب-يوجه هذا البحث عناية الباحثين اللى دور وطبيعة عمل أخصائى الإعلام التربوى ومدى لهدئه

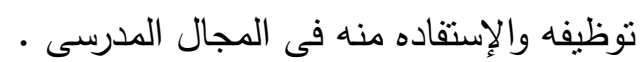

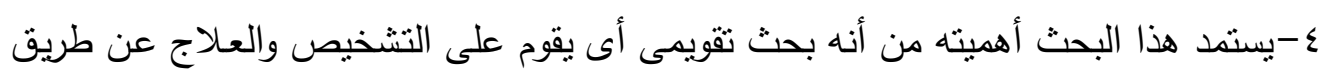
تحديد نقاط القوة وتعزيزها ونقاط الضعف . ه-تسهم هذه الدراسـة فى أن توفر للباحثين مادة علميـة عن دور و طبيعـة عمل أخصائى

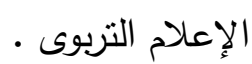

4-هذا البحث يساعد القائمين على أمر التعليم فى تحقيق الأهداف التعليمية المرجوة من وجود

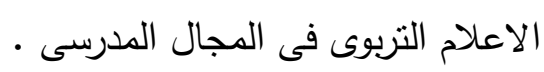
V-فيد هذا البحث فى تقديم مقترحات يستفاد منها فى تحسين الوضـح الحسالى لأخصائى

$$
\begin{aligned}
& \text { الإعلام التربوى وتطويره } \\
& \text { هدف البحث : } \\
& \text { يهدف البحث الحالى إلى : }
\end{aligned}
$$

تقويم دور أخصائى الإعلام التربوى فى ضوء المعايير القومية لضمان جودة التعليم والإعتماد ويتفرع من هذا الهدف عدة أهداف فرعية وهى :

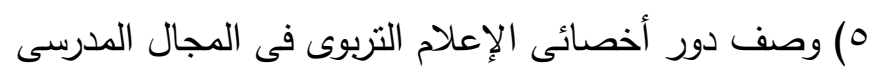

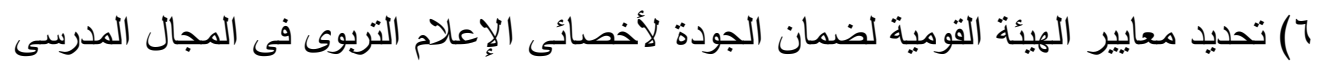

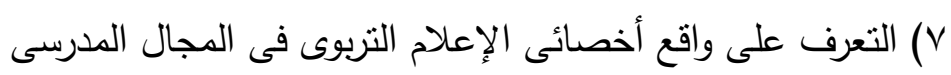

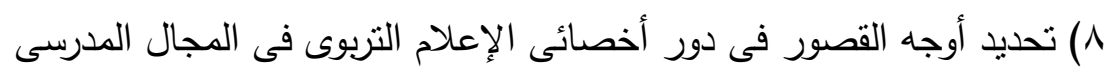

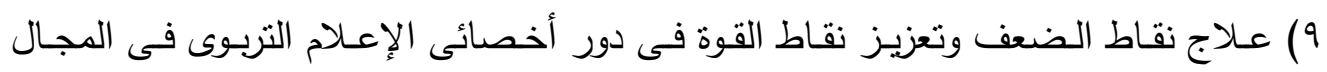

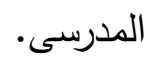




\section{مصطلحات البحث :}

- التقويم (Evaluation) : عمليـة التقويم "بأنها عمليـة منظمـة لجمـع وتحليل المعلومـات بغرض تحديد درجة تحقيق الأهداف التربوية واتخاذ القرارات بشأنها معالجة جوانب الضعف بانه

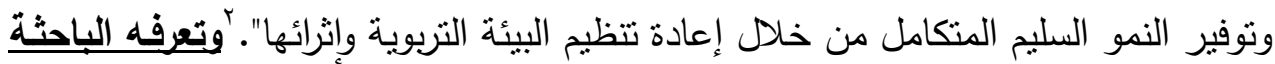
إجرائيا عملية تستتد إلى معايير محددة ، لتحديد جوانب القوة والضعف في الآداء من أجل أجل تعزيز نقاط القوة وعلاج نقاط الضعف ، ويرتبط هذا بالروئية والرسالة ، ويؤدى إلى التحسين المستمر من خلال وضع خطط تحسين الأداء .

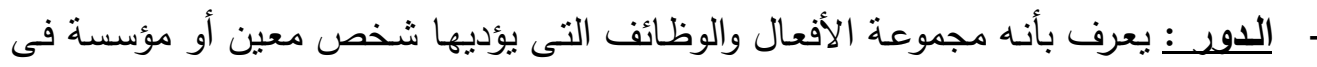

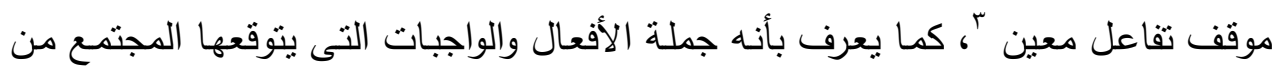

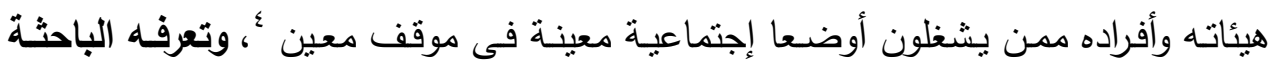

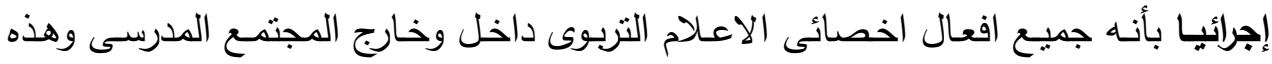

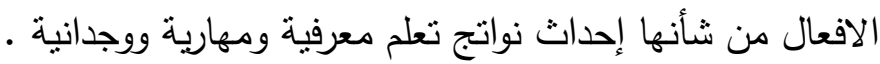
الإعلام التربوى : الوسيلة التى يتم من خلالها تزويد التلاميذ بالمعلومات الصادقة والحقائق

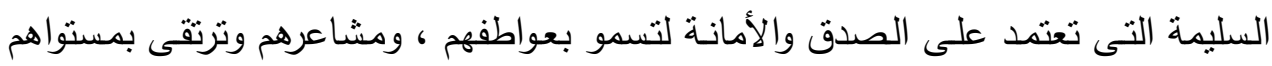

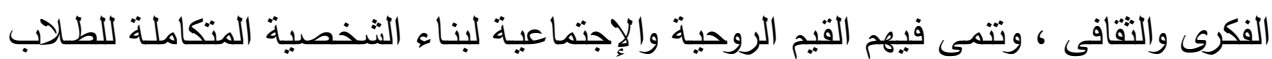

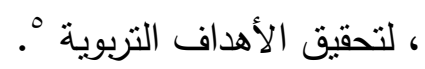
- أخصائحى الإعلام التريوي : تعرفه الباحثة إجرائيا بأنه : ويقصد به أخصائى الصحافة والإذاعة المدرسية الذى يقدم أنشطة إعلامية تربوية للمجمع المدرسى منها الصحافة المدرسية ، والإذاعة والبرلمان والمناظرو وكذلك حصص النشاط داخل الفصول ، والجماعات.

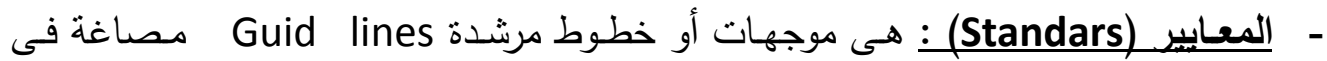

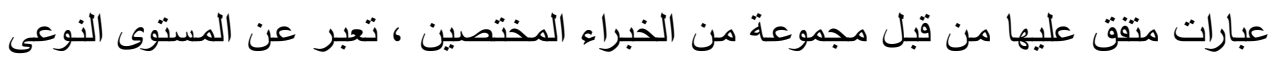
الذى يجب أن تكون عليع جميع مكونات العملية التعليمية. - ضـمان الجيودة : العمليـة الخاصـة بالتحقق من أن المعايير المتوافقة مع رساتلة المؤسسة

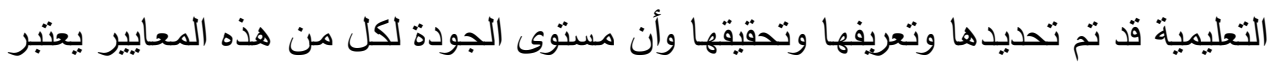
ملائما أو يفوق توقعات كافة أنواع المستقيدين النهائيين من المؤسسة التعليمية. 
- الإعتمـــ (Accreditation): الإعتراف الذى تمنحه الهيئة القومية لضمان جودة التعليم للمؤسسة التعليمية إذا تمكنت من إثبات إستيفائها وتحقيقها لمعايير الإعتمادالخاصـة بكل من القدرة المؤسسية والفاعلية التعليمية وفقا للمعايير المعلنة من الهيئة إستتادا إلى الشواهد

$$
\text { والأدلة '. }
$$

الارراسات السابقة :

المحور الأول: دراسات الدراسات المرتبطة بالإعلام التريوى :

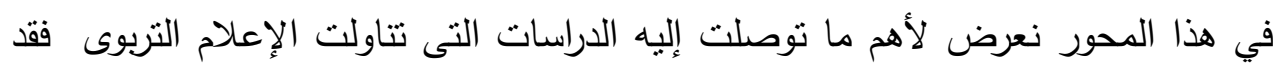

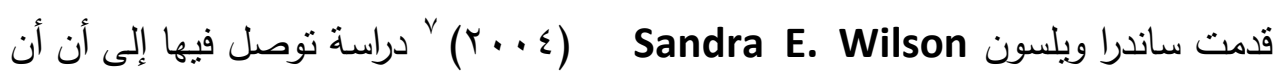
مشاركة الطلاب في أنشطة الإذاعة المدرسية تسهم إلي حد كبير في تتمية جوانب الذكاء

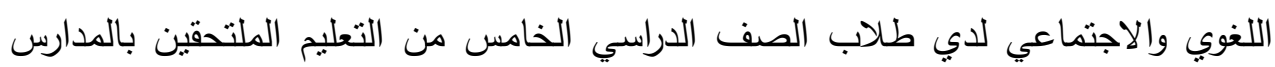
الإبندائية الواقعة في كل من المناطق الحضرية وشبه الحضرية من الولايات المتحدة

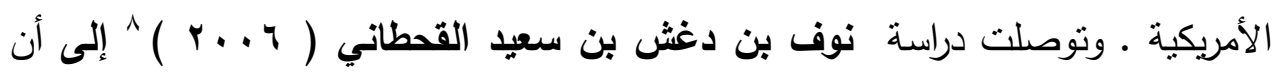

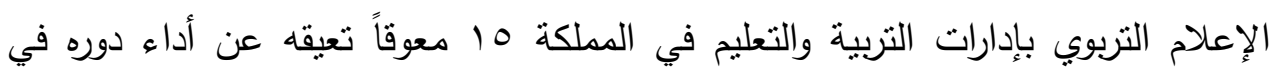
تفعيل مجالات العمل المدرسي واهم خمس معوقات هي قلة عدد العاملين في وحدة الإعلام

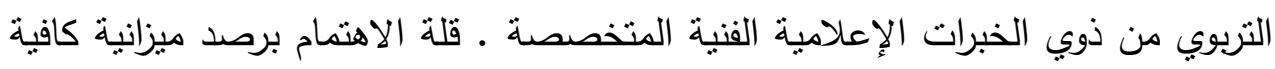

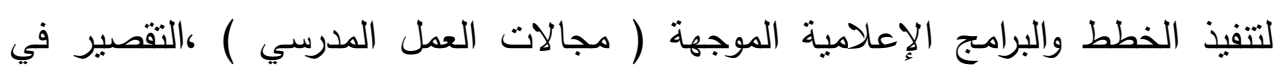
التتمية المهنية للعاملين في وحدة الإعلام التربوي من خلال الدورات التدريبية ـ القصور في الإعي التيدي فهم مفهوم الإعلام التربوي من قبل كثير من منسوبي الإدارة التعليمية علي اختلاف

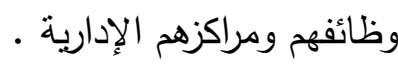

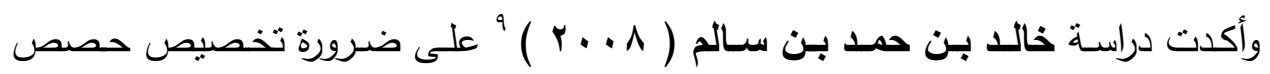

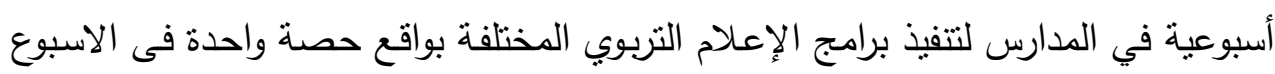

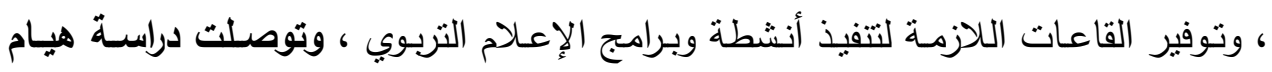

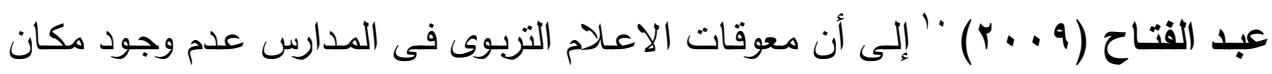

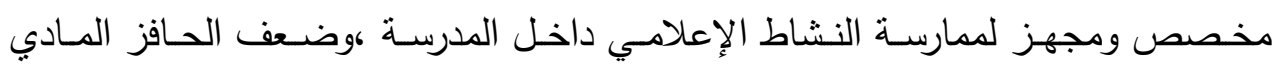

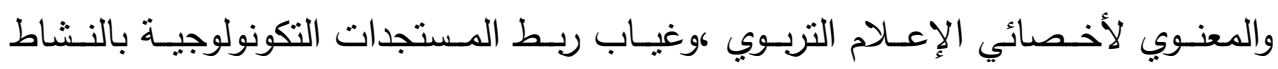

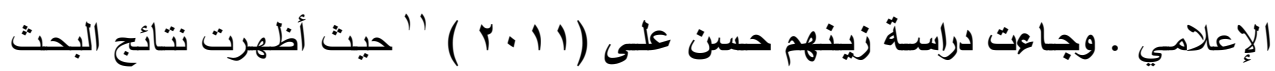
الميدانية بالنسبة للواقع الفعلى لدور أخصائى الإعلام المدرسى بالحلقة الثانية من التعليم 
الأساسى من وجهة نظر عينة البحث ، أن هنالك (Y Y) عبارة تتحقق بدرجة كبيرة ، وتتراوح

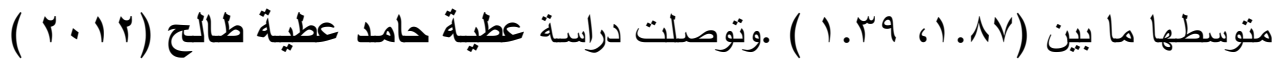

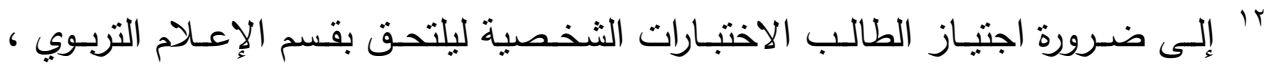

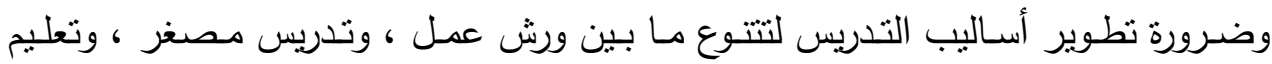

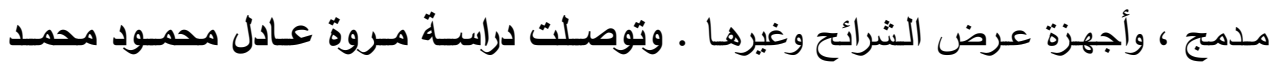

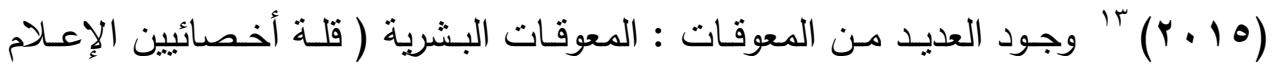
التربوى )، المعوقات المادية ( قلة الدعم المالى والفنى ) لمزاولة النشاط - جمود القرارات

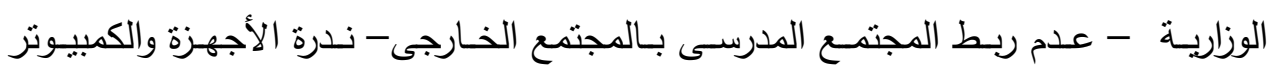
المستخدمة فى الإعلام التربوى .

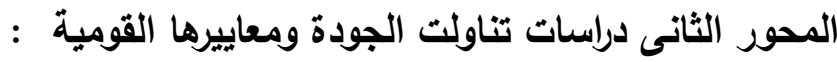

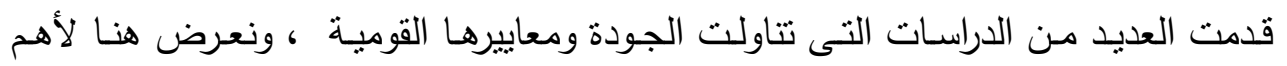

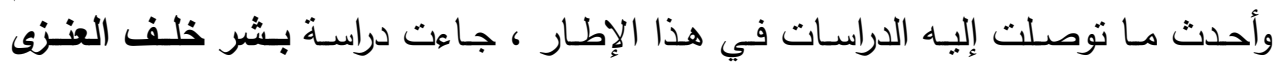

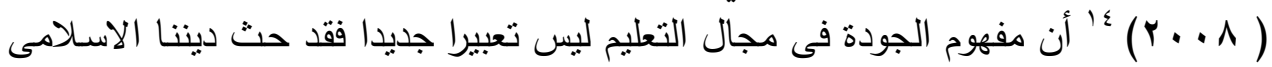

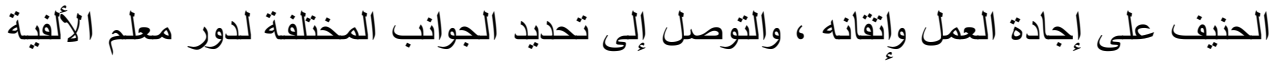

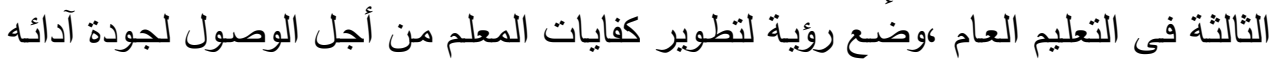

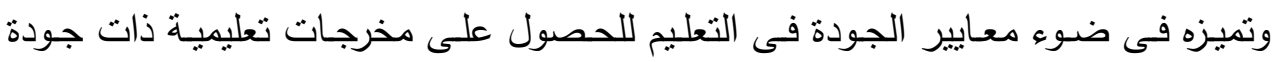

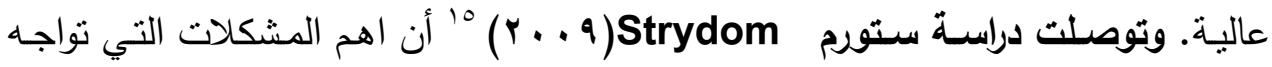

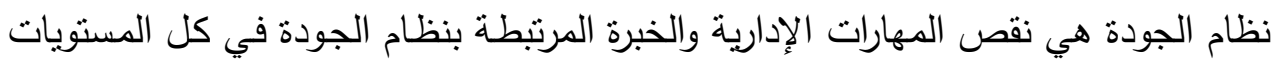

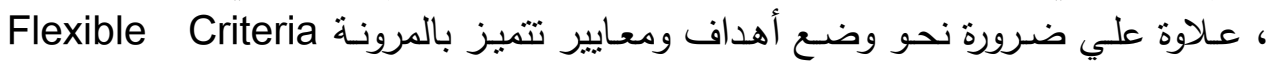

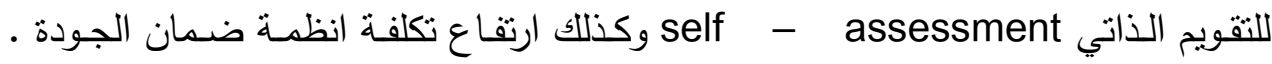

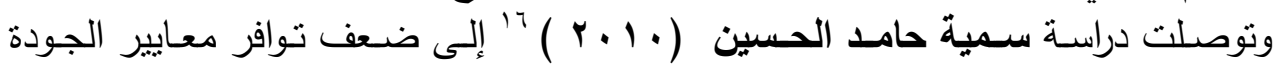

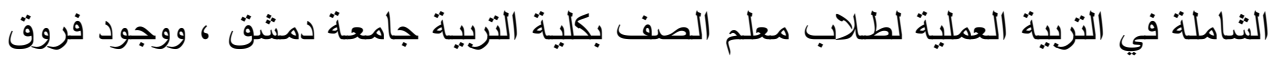

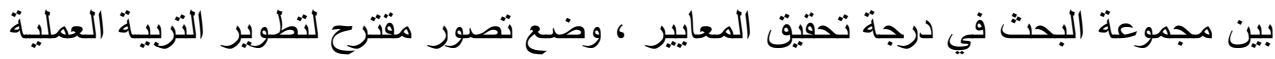

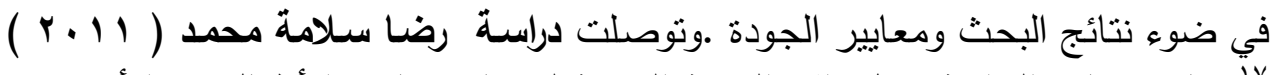

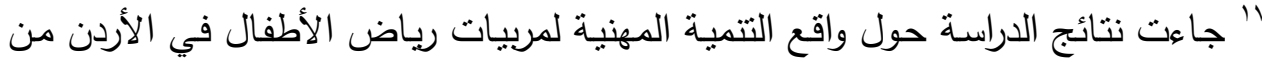

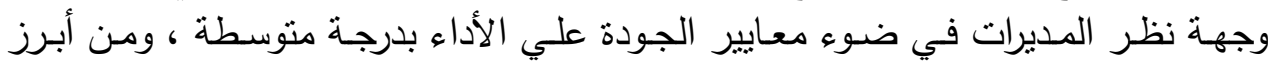

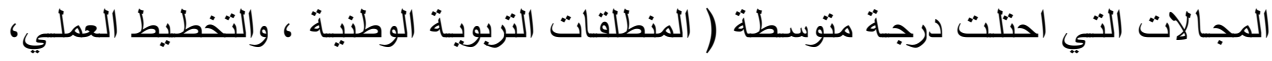

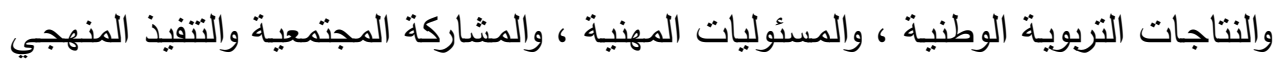

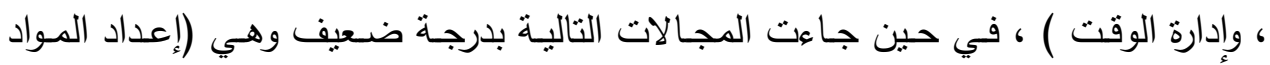

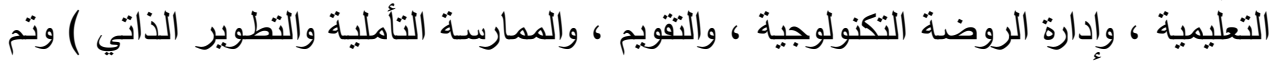

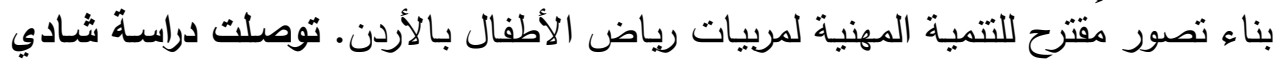




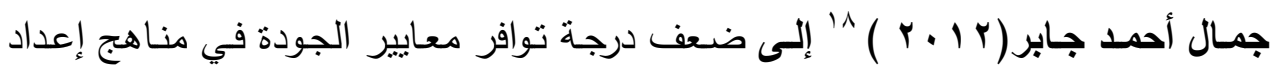

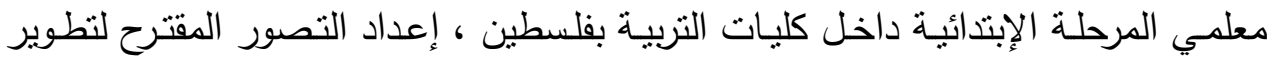

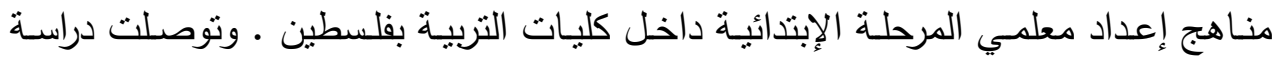

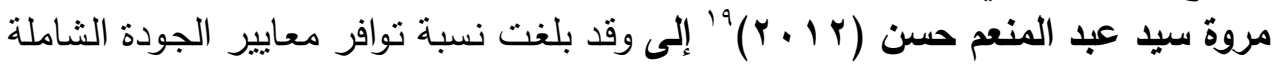

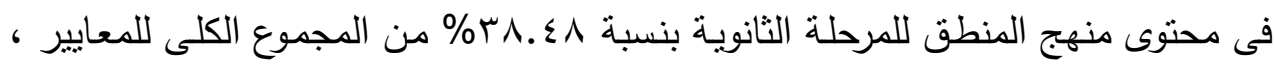

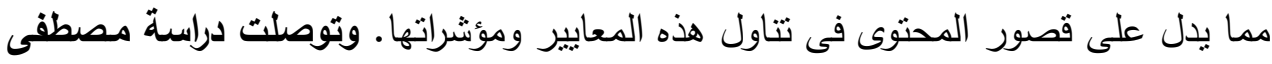

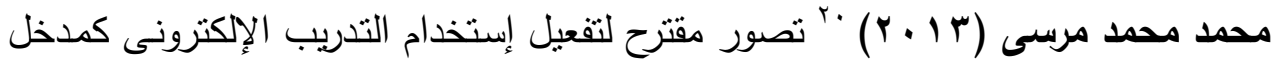

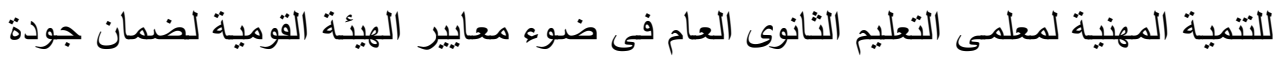

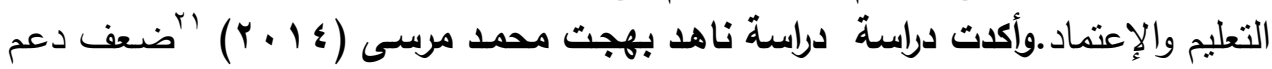

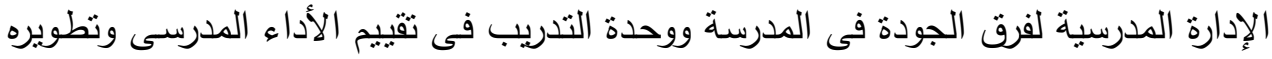

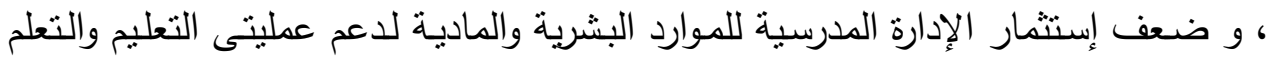
في المدارس. نوعية البحث :

ينتمى هذا البحث إلى البحوث الوصفية التى تستهدف تصنيف البيانات والحقائق التى تم

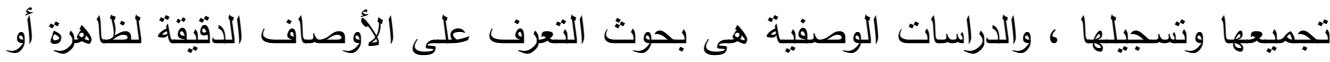

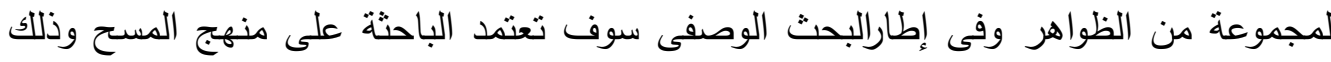

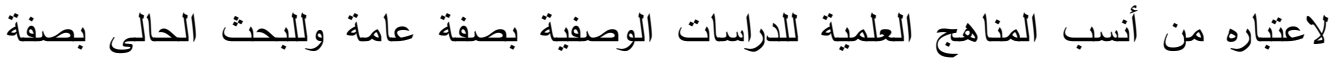

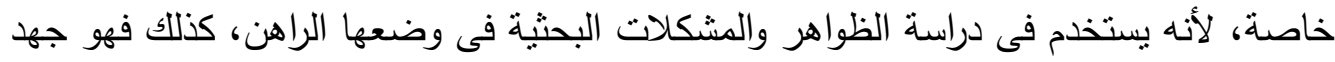

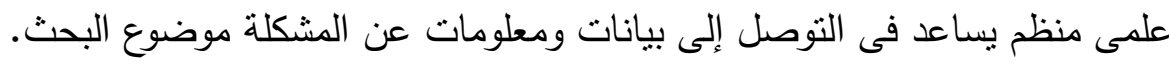

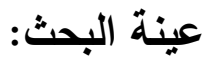

$$
\text { يعتمد البحث الحالى على البح: }
$$

1-عبنة عشوائية من أخصائى الإعلام التربوى بمحافظة الغربية من إداراتها العشر قوامها

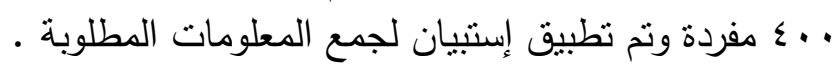

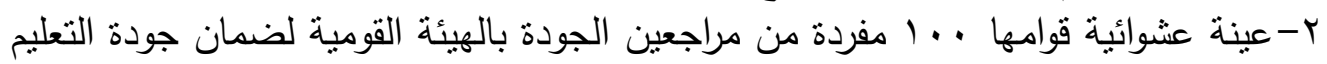

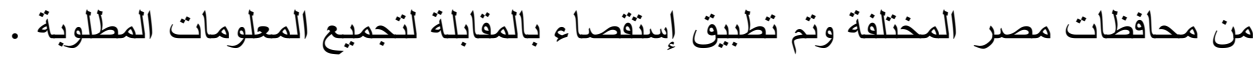

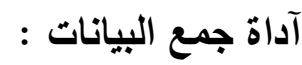

يعتمد البحث الحالى على أداة الإستبيان كآداة لجمع المعلومات عن عينة أخصائين

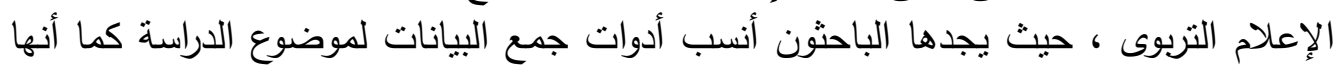

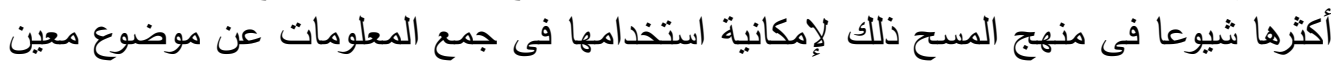

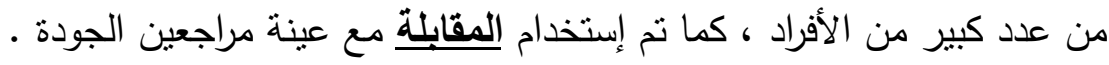

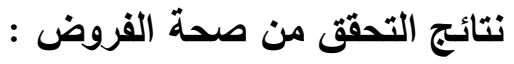
يحتوي هذا الجزء علي خلاصة ما توصلت إليه الدراسة الراهنة من نتائج تطبيق الاستبيان

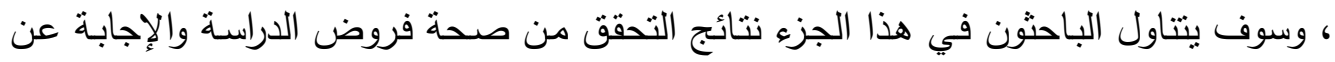


بعض تساؤلاتها البحثية ، ثم تقدم ملخصاً عن هذه النتائج ، والتي في ضوئها يمكن طرح عدد

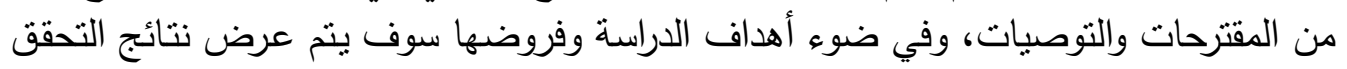

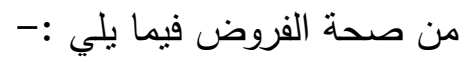

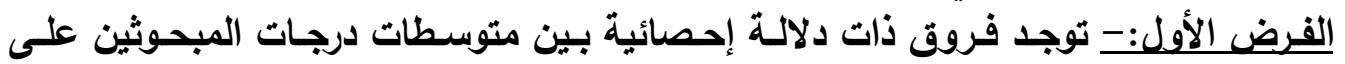

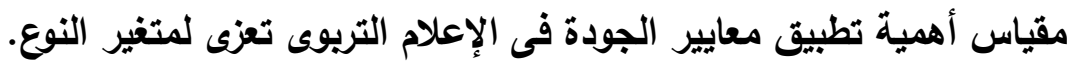
جدول (1)

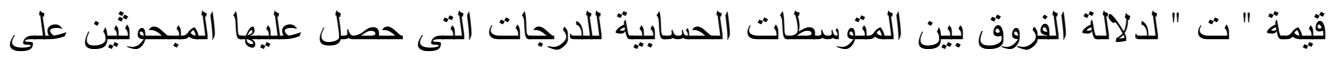

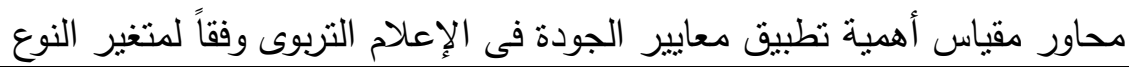

\begin{tabular}{|c|c|c|c|c|c|c|c|}
\hline مستوى الدلانة & الحرية & 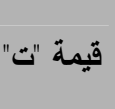 & الانحراف & المسابى المتوسط & 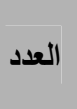 & مجموعات & المحوز \\
\hline \multirow{2}{*}{ غير } & \multirow{2}{*}{ rqג } & \multirow{2}{*}{.rTh } & $\cdot . \leqslant r$ & T.VV & 100 & ال الذكور & \multirow{2}{*}{ مجال الروئة والرسالة } \\
\hline & & & .0 & r.VA & $r \leq 0$ & الإناث & \\
\hline \multirow{2}{*}{ غير } & \multirow{2}{*}{ r१^ } & \multirow{2}{*}{$1 . \vee \vee 9$} & $.0 \%$ & r.TI & 100 & ال الذكور & \multirow{2}{*}{ مجال القيادة والحوكمة } \\
\hline & & &. .07 & r.01 & $r \leq 0$ & الإإناث & \\
\hline \multirow{2}{*}{ غير } & \multirow{2}{*}{ r१^ } & \multirow{2}{*}{.$\vee \vee \neg \varepsilon$} & . & r.9 & 100 & 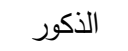 & \multirow{2}{*}{ مجال أهمية الموارد البشرية والمادية } \\
\hline & & & 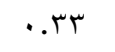 & r.91 & $r \leq 0$ & الإإناث & \\
\hline \multirow{2}{*}{ غير } & \multirow{2}{*}{ rq৯ } & \multirow{2}{*}{$1 . r$ To } &. .09 & 1.90 & 100 & الذكور & \multirow{2}{*}{ مجال أهمية المشاركة المجتمعية } \\
\hline & & &. .00 & $r . . r$ & $r \leqslant 0$ & ال إإناث & \\
\hline \multirow{2}{*}{ غير } & \multirow{2}{*}{ r৭^ } & \multirow{2}{*}{.90} & . & r.^o & 100 & 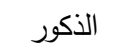 & \multirow{2}{*}{ مجال ضمان الجودة والمساعلة } \\
\hline & & &..$\leqslant \Gamma$ & r.^l & $r \leqslant 0$ & الإإناث & \\
\hline \multirow{2}{*}{ غير } & \multirow{2}{*}{ r৭^ } & \multirow{2}{*}{$1.1 \mathrm{r}$} &.$\cdot r$ & $r .90$ & 100 & 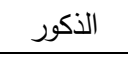 & \multirow{2}{*}{ مجال المتعلم } \\
\hline & & & 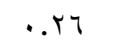 & r.9 & $r \leq 0$ & الإإناث & \\
\hline \multirow{2}{*}{ غير } & \multirow{2}{*}{ raı } & \multirow{2}{*}{$\cdot r \cdot \Lambda$} &.$r \Lambda$ & r.ی & 100 & الذكور & \multirow{2}{*}{ مجال المعلم } \\
\hline & & &..$r v$ & Y.AV & $r \leq 0$ & ال الإناث & \\
\hline \multirow{2}{*}{ غير } & \multirow{2}{*}{ rq৯ } & \multirow{2}{*}{.79} & $\cdot . \leqslant \wedge$ & r.vq & 100 & الذكور & \multirow{2}{*}{ مجال المنهج } \\
\hline & & & $\cdot . \leqslant 7$ & r.Ar & $r \leq 0$ & الإناث & \\
\hline \multirow{2}{*}{ غير } & \multirow{2}{*}{ rqג } & \multirow{2}{*}{. . } &. . & r.91 & 100 & الذكور & \multirow{2}{*}{ مجال المناخ التريوى } \\
\hline & & & & r.^9 & $r \leq 0$ & الإناث & \\
\hline
\end{tabular}

ينبين من خلال الجدول السابق عدم وجود فروق دالة إحصائياً عند مستوى ه ... بين متوسطات درجات المبحوثين على محساور مقياس أهميـة تطبيق معـايير الجودة فى الإعـلام

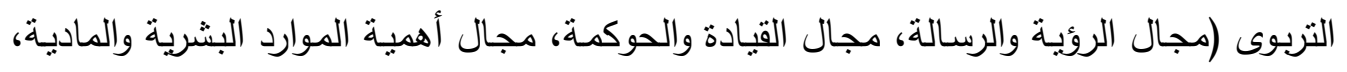

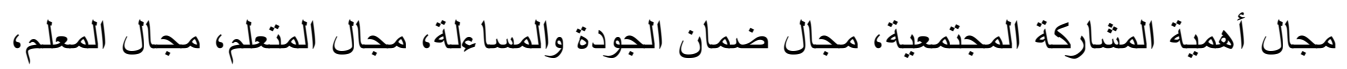


مجال المنهج، مجـال المنـاخ التربوى) تعزى لمتغير النوع، حيث كانت قيمـة " ت " الخاصـة بالمقارنـة بين متوسطات درجات الذكور ومتوسطات درجات الإناث على الأداة تلك المحاور

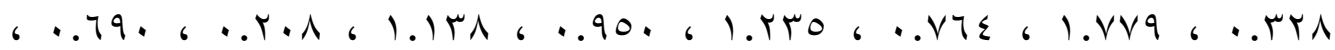

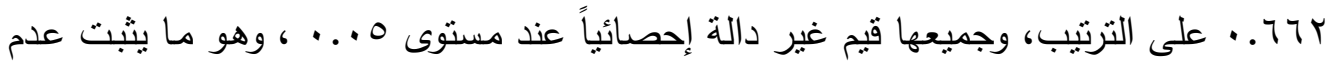

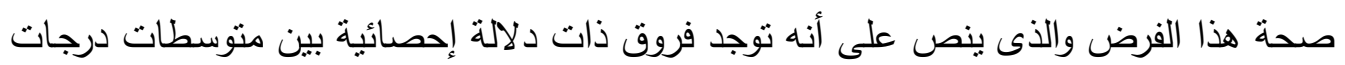
المبحوثين على مقياس أهمية تطبيق معايير الجودة فى الإعلام التربوى تعزى لمتغير النوع.

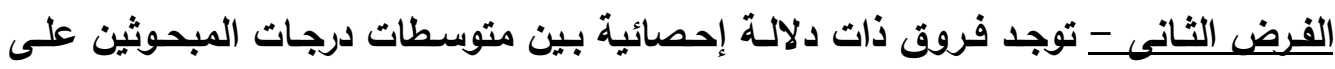
مقياس أهمية تطبيق معايير الجودة فى الإعلام التريوى تعزى لمتغير مكان المدرسة. جدول (r)

قيمة " ت " لدلالة الفروق بين المتوسطات الحسابية للارجات التى حصل عليها المبحوثين على

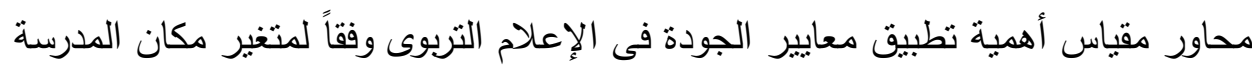

\begin{tabular}{|c|c|c|c|c|c|c|c|}
\hline الدلائة & الحريةة & قيمة "ت" & الانحراف المعيارى & المتوسط & العدد & مجموعات المقارنة & المحور \\
\hline \multirow{2}{*}{ دال } & \multirow{2}{*}{ rqA } & \multirow{2}{*}{ r..or } & .01 & r.VT & TrY & ريف & \multirow{2}{*}{ مجال الروئية والرسالة } \\
\hline & & &..$\leqslant r$ & r.Ar & IVA & حضر & \\
\hline \multirow{2}{*}{ غير } & \multirow{2}{*}{ rq^ } & \multirow{2}{*}{$.0 \leq 0$} &. $.0 \mathrm{~V}$ & r.or & rYT & ريف & \multirow{2}{*}{ مجال القيادة والحوكمة } \\
\hline & & & .01 & Y.07 & IVA & حضر & \\
\hline \multirow{2}{*}{ غير } & \multirow{2}{*}{ rqA } & \multirow{2}{*}{.009} & 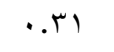 & r.9r & YYY & ريف & \multirow{2}{*}{ مجال أهمبة الموارد البشرية والمادية } \\
\hline & & & . r & r.91 & IVA & 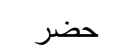 & \\
\hline \multirow{2}{*}{ 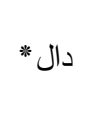 } & \multirow{2}{*}{ rqA } & \multirow{2}{*}{ r.. } & .07 & $1.9 \leq$ & YYY & ريف & \multirow{2}{*}{ مجال أهية المشاركة المجتمعية } \\
\hline & & &. .01 & r.. T & IVA & حضر & \\
\hline \multirow{2}{*}{ غير } & \multirow{2}{*}{ rqA } & \multirow{2}{*}{ M } &..$\leq \varepsilon$ & r.ᄉ. & YrT & ريف & \multirow{2}{*}{ مجال ضمان الجودة والمساعلة } \\
\hline & & & ס r. & Y.AT & $i v \wedge$ & حضر & \\
\hline \multirow{2}{*}{ غير } & \multirow{2}{*}{ rq人 } & \multirow{2}{*}{$\cdot . \leqslant 7 V$} & . ro & r.9r & rrt & ريف & \multirow{2}{*}{ مجال المتعلم } \\
\hline & & & 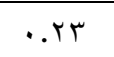 & r.9 & IVA & 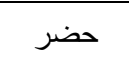 & \\
\hline \multirow{2}{*}{ غير } & \multirow{2}{*}{ rqA } & \multirow{2}{*}{.114} & 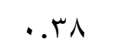 & Y.AV & YrT & ريف & \multirow{2}{*}{ مجال المعلم } \\
\hline & & & 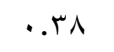 & $r . \wedge \wedge$ & IVA & 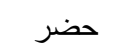 & \\
\hline \multirow{2}{*}{ غير } & \multirow{2}{*}{ rq } & \multirow{2}{*}{.911} &..$\leqslant 9$ & r.Vq & YrT & ريف & \multirow{2}{*}{ مجال المنهج } \\
\hline & & &..$\leq \varepsilon$ & r.Ar & IVA & حضر & \\
\hline \multirow{2}{*}{ غير } & \multirow{2}{*}{ rq^ } & \multirow{2}{*}{1.011} & r & r.9r & rtr & ريف & \multirow{2}{*}{ مجال المناخ التريوى } \\
\hline & & & و מ.. & Y.AV & IVA & حضر & \\
\hline
\end{tabular}


يتبين مـن خـلال الجدول السابق وجـود فروق دالـة إحصائياً عند مستوى ه. . . بـين

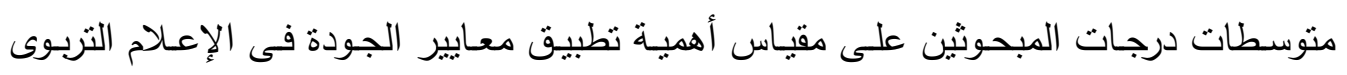
تعزى لمتغير مكان المدرسة، حيث كانت قيمة " ت " الخاصة بالمقارنة بين متوسطات درجات مبحوثى مدارس المناطق الريفية ومنوسطات درجات مبحوثى المناطق الحضرية على محاور مقياس أهمية تطبيق معايير الجودة فى الإعلام التربوى (مجال الرؤية والرسالة، مجال أهمية

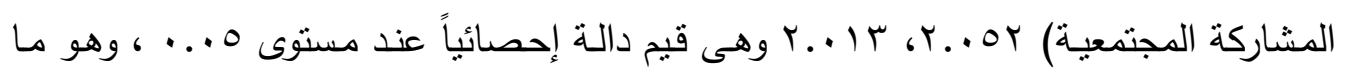
يثبت صحة هذا الفرض والذى ينص على أنه توجد فروق ذات دلالة إحصائية بين متوسطات درجات المبحوثين على مقياس أهمبة تطبيق معايير الجودة فى الإعلام التربوى تعزى لمتغير

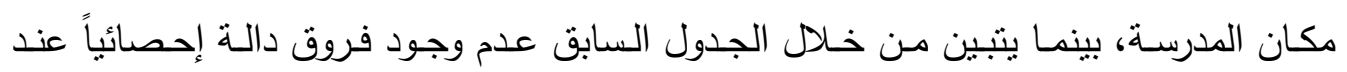

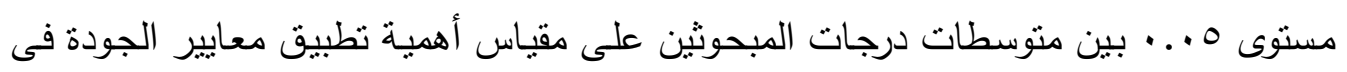
الإعلام التربوى تعزى لمتغير مكان المدرسـة، حيث كانت قيمة " ت " الخاصـة بالمقارنـة بين متوسطات درجـات مبحـوثى مـدارس المنـاطق الريفيـة ومتوسطات درجـات مبحـوثى المنـاطق الحضرية على محاور مقياس أهمية تطبيق معايير الجودة فى الإعلام التربوى (مجال القيادة

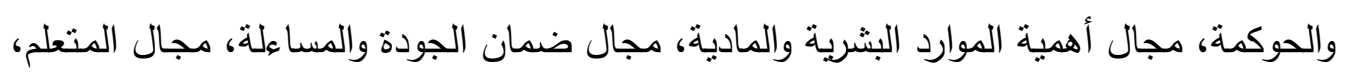

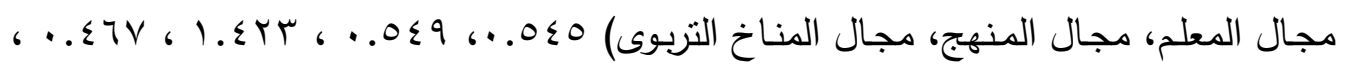

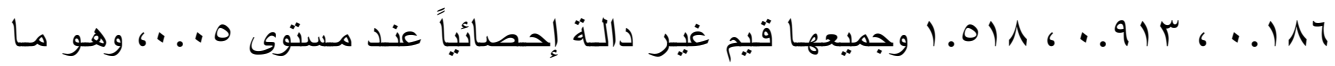
يثبت عدم صحة هذا الفرض والذى ينص على أنه توجد فروق ذات دلالـة إحصائية بين متوسطات درجات المبحوثين على مقياس أهمية تطبيق معايير الجودة فى الإعلام التربوى فيما

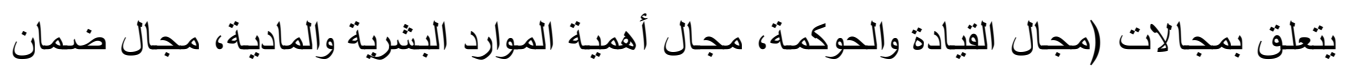

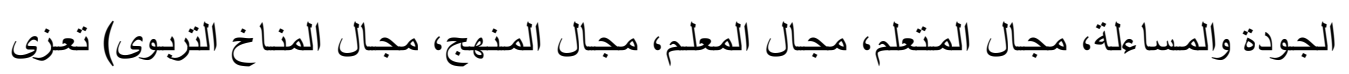
لمتغير مكان المدرسة. الفـرض الثالث: توجد فروق ذات دلالـة إحصائية بين متوسطات درجـات المبحوثين على مقيـاس أهميـة تطبيق معـايير الجـودة في الإعـلام التربـوى تعزى لمتغيـر

$$
\text { المرحلة التعليمية (ابتدائي - إعدادي - ثانوى). }
$$




\section{جدول (r)}

قيمة " ف " لدلالة الفروق بين المتوسطات الحسابية للدرجات التى حصل عليها الطلاب على

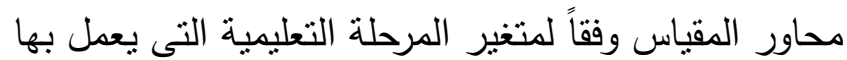

\begin{tabular}{|c|c|c|c|c|c|c|}
\hline الدلالة & قيمة ف & متوسط مجموع & درجة & مجموعات المربعات & مصدر التباين & المحور \\
\hline \multirow{3}{*}{ غير } & \multirow{3}{*}{ 1.ᄉㅅ } &..$\Sigma 1 \wedge$ & r &.$\wedge \varepsilon$ & بين المجموعات & \multirow{3}{*}{ مجال الروية } \\
\hline & & מצT & rqV & AN.ru & داخل المجموعاث & \\
\hline & & & rq9 & Aq.r. & المجمـوع & \\
\hline \multirow{3}{*}{ غير } & \multirow{3}{*}{$\because \vee 0 \wedge$} & ונזיט. & r & $\cdot . \leq 7$ & بين المجموعات & \multirow{3}{*}{ مجال القيادة } \\
\hline & & $\cdot r \cdot \varepsilon$ & rqV & Ir..Vr & داخل المجموعات & \\
\hline & & & एqq & 141.19 & المجمـوع & \\
\hline \multirow{3}{*}{ غير } & \multirow{3}{*}{.+01} & ..rv & r & $\cdots v$ & بين المجموعات & \multirow{3}{*}{ مجال أهمية الموارد } \\
\hline & & $\because 1 \cdot \varepsilon$ & rqV & \&l. TV & داخل المجموعات & \\
\hline & & & rq9 & $\varepsilon 1 . \leqslant \varepsilon$ & المجمـوع & \\
\hline \multirow{3}{*}{ غير } & \multirow{3}{*}{ r.人Ir } & $.9 \cdot 1$ & r & $1 . \wedge$. & بين المجموعات & \multirow{3}{*}{ مجال أهمية المشاركة } \\
\hline & & . & rqV & IrV.11 & داخل المجموعات & \\
\hline & & & एqq & $1 Y \wedge .91$ & المجمـوع & \\
\hline \multirow{3}{*}{ غير } & \multirow{3}{*}{$\because 10$} & .. ro & r &. .0 & بين المجموعات & \multirow{3}{*}{ الجودة والمساعلة ضمان } \\
\hline & & $.17 \varepsilon$ & rqv & $70 . .0$ & داخل المجموعات & \\
\hline & & & एqq & 70.1. & المجمـوع & \\
\hline \multirow{3}{*}{ غير } & \multirow{3}{*}{. .091} & ... To & r & $\cdots v$ & بين المجموعات & \multirow{3}{*}{ مجال المتعلم } \\
\hline & & $\ldots 09$ & rqv & & داخل المجموعات & \\
\hline & & & एqq & rT. & المجمـوع & \\
\hline \multirow{3}{*}{$\begin{array}{c}* * 4 \\
*\end{array}$} & \multirow{3}{*}{ 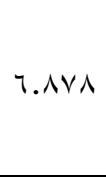 } & $.9 \leq 7$ & r & 1.19 & بين المجموعات & \multirow{3}{*}{ مجال المعلم } \\
\hline & & 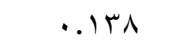 & rqV & $0 \leq .71$ & داخل المجموعات & \\
\hline & & & एqq & 07.0. & المجمـوع & \\
\hline \multirow{3}{*}{ غير } & \multirow{3}{*}{.$\neg \wedge \varepsilon$} & .0101 & r & .r. & بين المجموعات & \multirow{3}{*}{ مجال المنهج } \\
\hline & &.$Y_{1}$ & rqv & $\wedge \vee . \wedge \vee$ & داخل المجموعات & \\
\hline & & & एqq & $\wedge \wedge . \mid \wedge$ & المجمـوع & \\
\hline \multirow{3}{*}{ غير } & \multirow{3}{*}{ q } & $.10 \leqslant$ & r & ו ו & بين المجموعات & \multirow{3}{*}{ مجال المناخ } \\
\hline & & $.1 Y \varepsilon$ & rqV & $\varepsilon 9 . Y \wedge$ & داخل المجموعات & \\
\hline & & & rqq & $\varepsilon 9.09$ & المجمـوع & \\
\hline
\end{tabular}


تشير بيانات الجدول السابق إلى وجود فروق ذات دلالة إحصائية بين منوسطات درجات

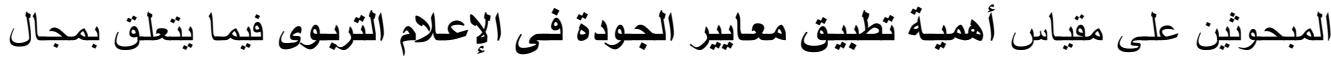

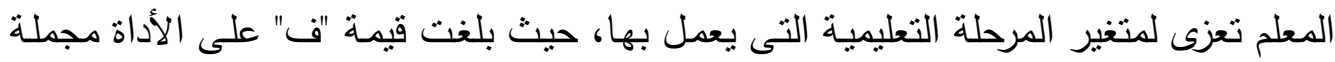

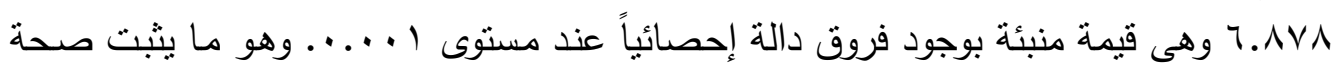

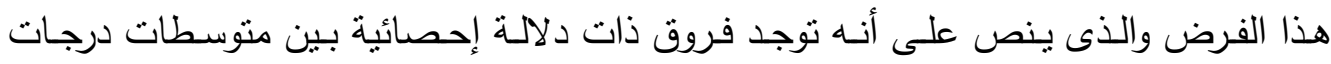

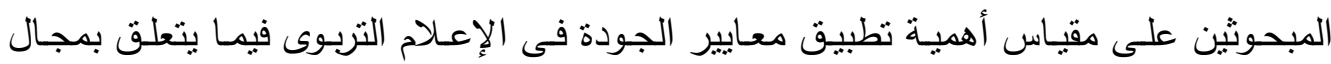

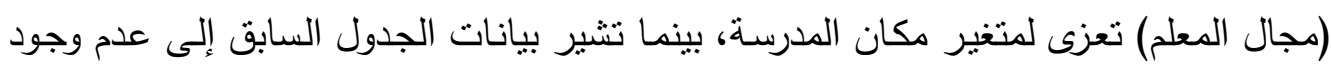
فروق ذات دلالة إحصائية بين متوسطات درجات المبحوثين على محاور مقياس أهمية تطبيق الماني

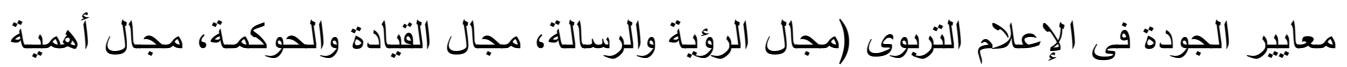

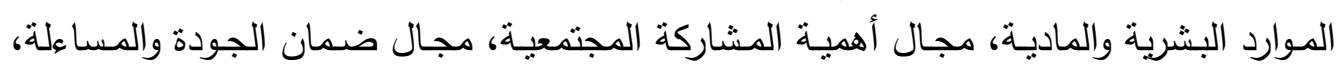

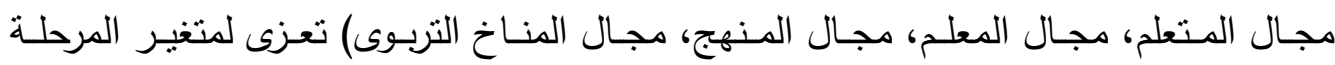

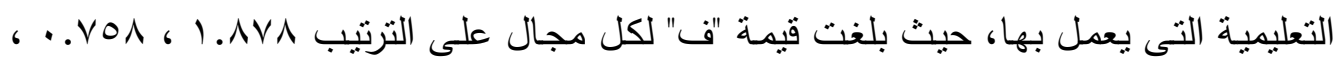

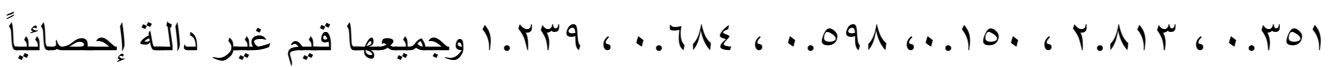

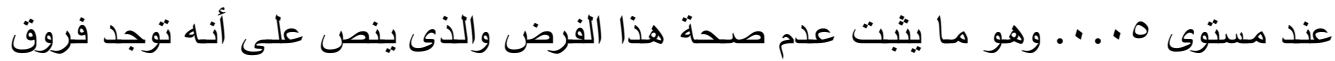

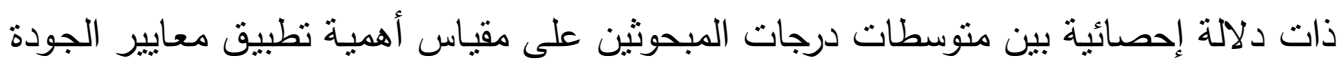

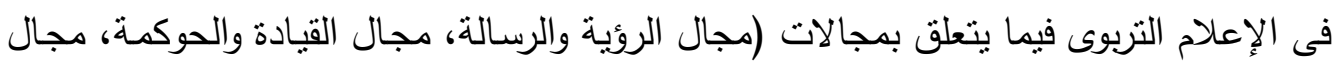

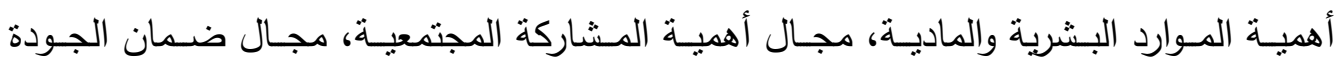

والمساءلة، مجال المتعلم، مجال المنهج، مجال المناخ التربوى) تعزى لمتغير مكان المدان المدرسة.

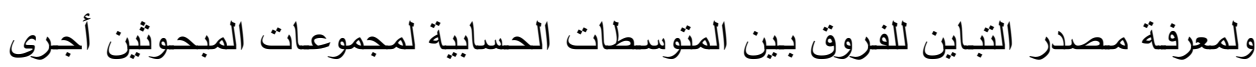

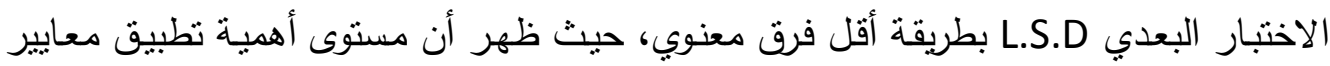

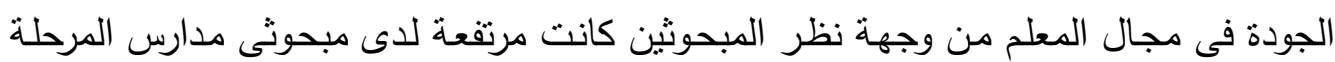
الإعدادية أكبر من المرحلة الابتدائية والثانوية.

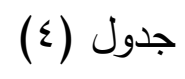

نتائج تحليل L.S.D لمعرفة القروق بين المجموعات علي مقياس أهمية تطبيق معايير الجودة فى الإعلام التريوى

\begin{tabular}{|c|c|c|c|c|c|}
\hline المتوسط & الثانوية & الإعدادية & الابتدائية & المجموعات & الاور \\
\hline 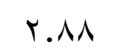 & & & - & الابتدائية & \multirow{3}{*}{ مجال } \\
\hline$r .90$ & & - & $\ldots v \leqslant 1$ & الإعدادية & \\
\hline r.VT & - & $* * * .1109$ & $* . .1111$ & الثانوية & \\
\hline
\end{tabular}


أولاً: فيما يتعلق بأهميـة تطبيق معايير الجـودة فى مجال المعلم من وجهة نظر المبحوثين، حيث اتضـح أن هنالك اختلافًا بين مبحوثى المدارس الإعداديـة ومبحوثى المدارس الثانوية بفرق بين المتوسطين الحسابيين بلغ 109 ا. . لصالح مبحوثى المدارس إس

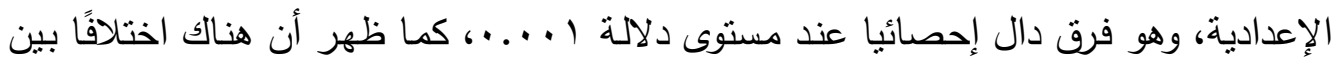

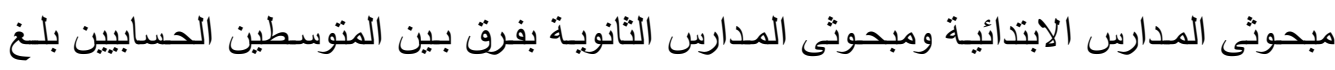

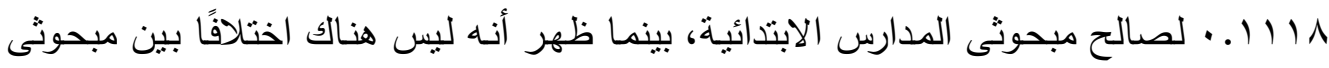
المدارس الإعداديـة ومبحوثى المدارس الابتدائية، حيث بلـغ الفرق بين المتوسطين الحسابيين

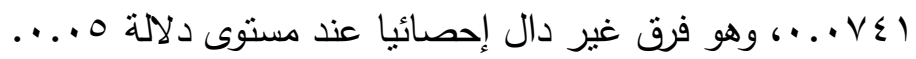

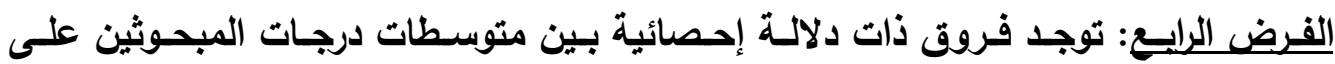

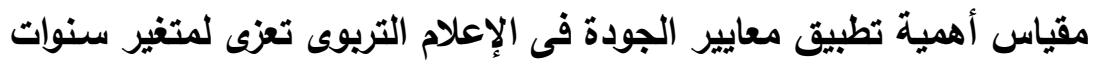
الخبرة (أقل من ثُلاث سنوات- من ثُلاث إلى أقل من سبع سنواته - من من سبع

\section{سنوات فأكثر).}

\section{جدول (0)}

قيمة " ف " لدلالة الفروق بين المتوسطات الحسابية للدرجات التى حصل عليها الطلاب على محاور المقياس وفقاً لمتغير سنوات الخبرة

\begin{tabular}{|c|c|c|c|c|c|c|}
\hline الدالة الدالة & قيمة ف & متوسط مجموع & الحرية & مجموعات المريعات & مصدر التباين & المحور \\
\hline \multirow{3}{*}{ 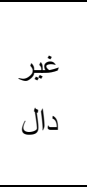 } & \multirow{3}{*}{ ITM } & ..or & r & $\because 1$ & بين المجموعات & \multirow{3}{*}{ مجال الروية والرسالة } \\
\hline & & $. r Y \leq$ & rav & $19 . .9$ & داخل المجموعات & \\
\hline & & & r99 & N9.r. & المجمـوع & \\
\hline \multirow{3}{*}{ غير } & \multirow{3}{*}{ r.rAN } & $\because V T$. & r & $1 . \varepsilon \varepsilon$ & بين المجموعات & \multirow{3}{*}{ والحوكمة القيادة } \\
\hline & & $\cdot r \cdot r$ & rqv & 119.80 & داخل المجموعات & \\
\hline & & & rq9 & 141.19 & المجمـوع & \\
\hline \multirow{3}{*}{ 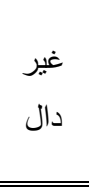 } & \multirow{3}{*}{.$\cdot r$} & $\cdots \cdots 1$ & r & $\cdots$ & بين المجموعات & \multirow{3}{*}{ مجال أهمية الموارد } \\
\hline & & $\cdot .1 \cdot \varepsilon$ & rav & $\varepsilon 1 . \leqslant \varepsilon$ & داخل المجموعات & \\
\hline & & & rq9 & $\varepsilon 1 . \leqslant \varepsilon$ & المجمـوع & \\
\hline \multirow{3}{*}{ 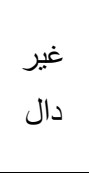 } & \multirow{3}{*}{1.990} & $. . T \leq r$ & r & $1 . r \wedge$ & بين المجموعات & \multirow{3}{*}{ المشاركة المجتمعية أهمية } \\
\hline & & DTH & rav & IrV.79 & داخل المجموعات & \\
\hline & & & rq9 & $1 Y \wedge .91$ & المجمـوع & \\
\hline
\end{tabular}




\begin{tabular}{|c|c|c|c|c|c|c|}
\hline \multirow{3}{*}{ دال ** } & \multirow{3}{*}{ T.TV. } &. $.99 V$ & r & 1.99 & بين المجموعات & \multirow{3}{*}{ مجال ضمان الجودة } \\
\hline & & .109 & rqV & . & داخل المجموعات & \\
\hline & & & ए११ & 70.1. & المجمـوع & \\
\hline \multirow{3}{*}{ دال *** } & \multirow{3}{*}{9.110} & $. .01 \leq$ & r & $1 . . r$ & بين المجموعات & \multirow{3}{*}{ مجال المتعلم } \\
\hline & &. .07 & rqV & YY.SI & داخل المجموعات & \\
\hline & & & एवq & rT. $\varepsilon \varepsilon$ & المجمـوع & \\
\hline \multirow{3}{*}{ غير } & \multirow{3}{*}{.11 . } & $\cdots 17$ & r & $\ldots r$ & بين المجموعات & \multirow{3}{*}{ مجال المعلم } \\
\hline & & $.1 \leq r$ & rqv & $07 . \leqslant V$ & داخل المجموعات & \\
\hline & & & एव9 & 07.0. & المجمـوع & \\
\hline \multirow{3}{*}{ غير } & \multirow{3}{*}{$.71 r$} & o & r &..$r V$ & بين المجموعات & \multirow{3}{*}{ مجال المنهج } \\
\hline & &.$M Y I$ & rav & AV.91 & داخل المجموعات & \\
\hline & & & एव१ & $\wedge \wedge . \wedge$ & المجمـوع & \\
\hline \multirow{3}{*}{ غير } & \multirow{3}{*}{$1 . .74$} & . & r &..$Y_{T}$ & بين المجموعات & \multirow{3}{*}{ مجال المناخ } \\
\hline & & $. .1 Y \leq$ & rqV & $\varepsilon q . r \mu$ & داخل المجموعات & \\
\hline & & & एवq & $\varepsilon 9.09$ & المجمـوع & \\
\hline
\end{tabular}

تشير بيانات الجدول السابق إلى وجود فروق ذات دلالة إحصائية بين متوسطات درجات المبحوثين على مقياس أهمبة تطبيق معايير الجودة فى الإعـلام التربـوى فيما يتعلق بمجال (مجـال ضـمان الجودة والمساعلة ، مجـال المـتمل) تعزى لمتغير سنوات الخبرة فى المجال،

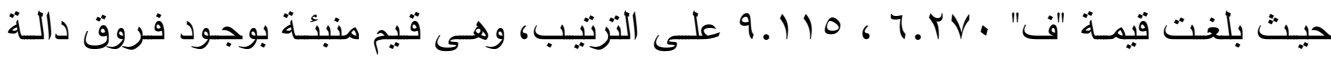
إحصائياً عند مستوى ( . .. ، 1 . . . . . على الترتيب وهو ما يثبت صحة هذا الفرض والذى ينص على أنه توجد فروق ذات دلالة إحصائية بين منوسطات درجات المبحوثين على مقياس أهميـة تطبيتق معـايير الجودة فيى الإعـلام التربوى فيمـا يتعلق بمجـال (مجـال ضـمان الجـودة والمساءلة ، مجال المتعلم) تعزى لمتغير سنوات الخبرة فى المجال، بينما نشير بيانات الجدول السابق إلى عدم وجود فروق ذات دلالة إحصائية بين منتسطات درجات المبحوثين على محاور مقياس أهمية تطبيق معايير الجودة فى الإعلام التربوى (مجال الرؤبة والرسالة، مجال القيادة والحوكمـة، مجـال أهميـة المـوارد البشرية والماديـة، مجـال أهميـة المششاركة المجتمعيـة، مجـال المعلم، مجال المنهج، مجال المناخ التربوى) تعزى لمتغير سنوات الخبرة فى المجال، حيث.

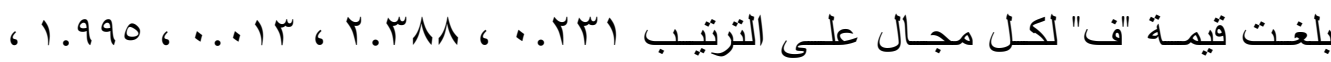

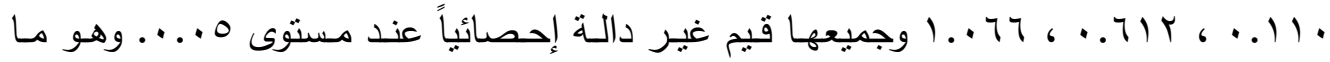


يثبت عدم صحة هذا الفرض والذى ينص على أنسه توجد فروق ذات دلالـة إحصائية بين متوسطات درجات المبحوثين على مقياس أهمية تطبيق معايير الجودة فى الإعلام التربوى فيما

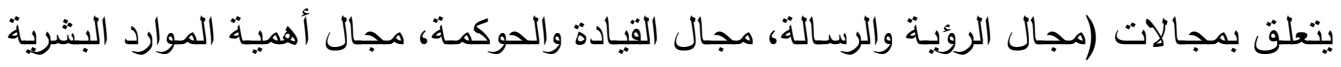

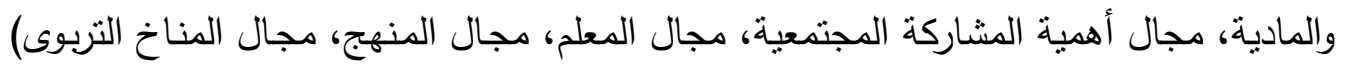
تعزى لمتغير سنوات الخبرة فى المجال.

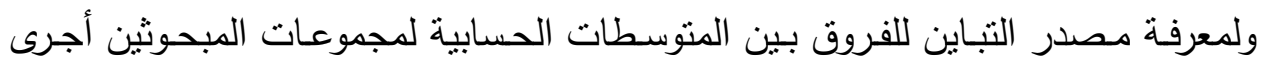
الاختبار البعدي L.S.D بطريقة أقل فرق معنوي، حيث ظهر أن مستوى أهمية نطبيق معايير

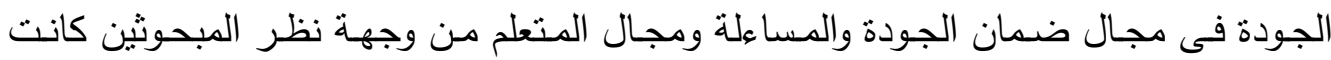
مرتفعة لدى المبحوثين مرتفعى سنوات الخبرة من سبع سنوات فأكثر .

$$
\text { جدول (T) }
$$

نتائج تحليل L.S.D لمعرفة الفروق بين المجموعات علي مقياس أهمية تطبيق معايير الجودة فى الإعلام

\begin{tabular}{|c|c|c|c|c|c|}
\hline \multicolumn{6}{|c|}{ التريوى } \\
\hline المتوسط & فن سبع سنوات & من مبع سنوات إلى & أقل من ثلاث سنوات & المجموعات & المحاور \\
\hline$r .00$ & & & - & أقل من ثلاث سنوات & مجال \\
\hline r.یI & & - & $* *$. หนาร & من ثلاث إلى أقل من & ل الجودة \\
\hline r.10 & - & $\ldots \leqslant r V$ & $* * * . . \Gamma 1.1$ & من سبع سنوات فأكثر & والمساءلة \\
\hline T.VT & & & - & أقل من ثلاث سنوات & \\
\hline T. $9 \varepsilon$ & & - & ****. . Y Y T Y & من ثلاث إلى أقل من & 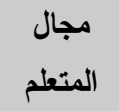 \\
\hline$r .90$ & - & $\ldots .1$. & ****..YYYY & من سبع سنوات فأكثر & \\
\hline
\end{tabular}

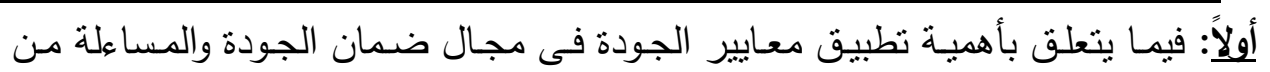

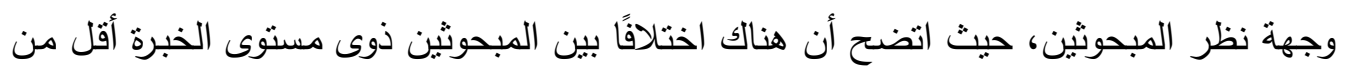

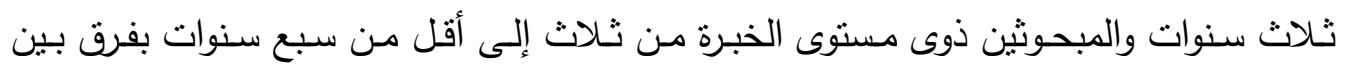

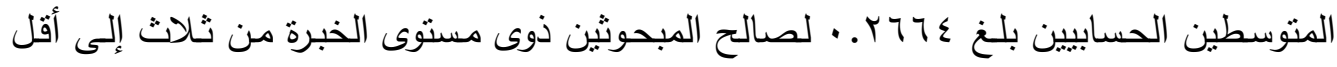
من سبع سنوات، وهو فرق دال إحصائيا عند مستوى دلالة ا ...، كما ظهر أن هناك اختلافًا

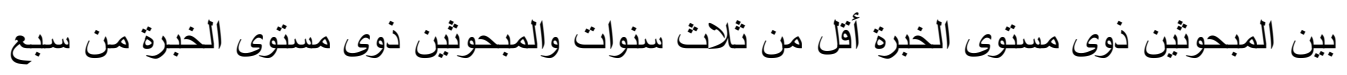

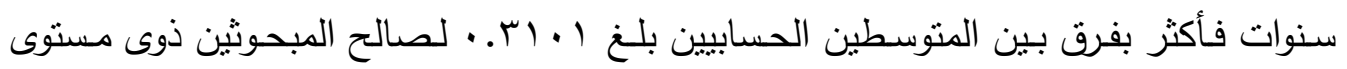


الخبرة من سبع سنوات فأكثر ، وهو فرق دال إحصائيا عند مستوى دلالة ا (....، بينما ظهر

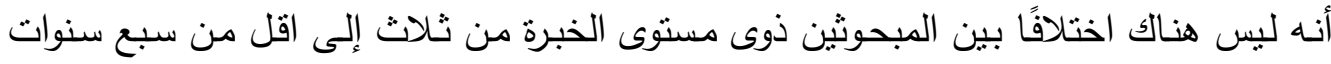

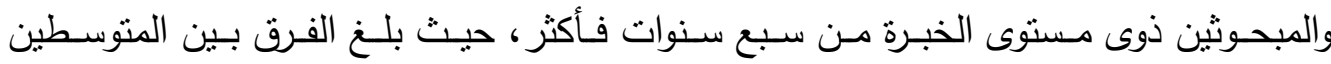
الحسابيين VT؟ ...، وهو فرق غير دال إحصائيا عند مستوى دلالة ه.....

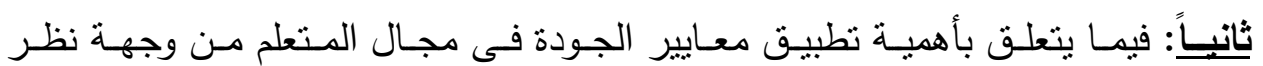

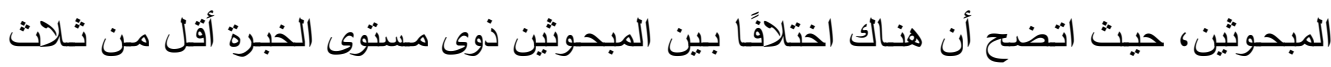
سنوات والمبحوثين ذوى مستوى الخبرة من ثلاث إلى أقل من سبع سنوات بفرق بين المتوسطين

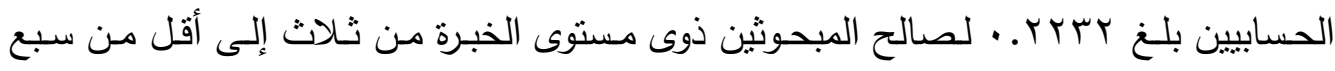
سنوات، وهو فرق دال إحصائيا عند مستوى دلالة ال.....، كما ظهر أن هناك اختلافًًا بين المبحوثين ذوى مستوى الخبرة أقل من ثلاث سنوات والمبحوثين ذوى مستوى الخبرة من سبع

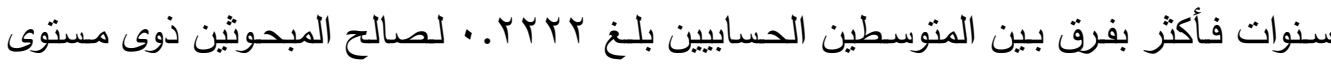

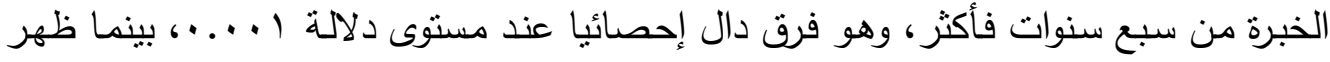

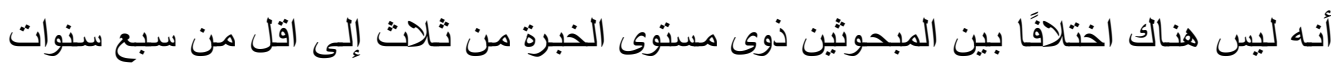

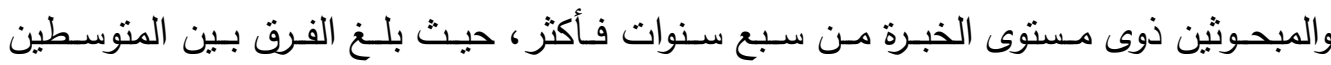

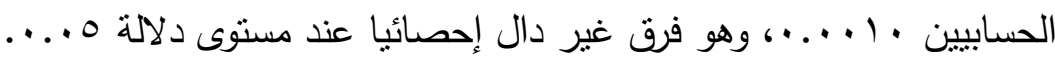
الفرض الخامس: توجد فروق ذات دلالة إحصائية بين عينة الأخصائيين وعينة المراجعين فى دي دهي تعديد أهم المعوقات التى تواجه نشاط الإعلام التربوى.

$$
\text { جدول رقم (v) }
$$

أهم المعوقات التى تواجه نشاط الإعلام التريوى من وجهة نظر المراجعين والأخصائيين.

\begin{tabular}{|c|c|c|c|c|c|c|c|c|c|}
\hline \multirow{2}{*}{ 雪: } & \multirow{2}{*}{ الالالة } & \multirow{2}{*}{ قيمة z } & \multicolumn{2}{|c|}{ الإجمالي } & \multicolumn{2}{|c|}{ الأخصائيين } & \multicolumn{2}{|c|}{ المراجعين } & \multirow{2}{*}{ أهم المعوقات } \\
\hline & & & $\%$ & ك & $\%$ & ك & $\%$ & ك & \\
\hline V & غالة & 1.910 & $71 . .$. & r & $v \ldots$ & $r \wedge$. & $7 \ldots$ & 7. & 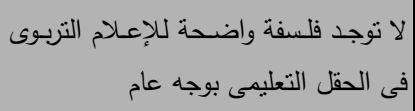 \\
\hline 1 & | دالة*** & T.VYT & $9 \ldots$ & $\leqslant 0$. & $\wedge \vee .0$. & ro. & $1 \cdots$ & $1 \ldots$ & الإعلام التربوى فـى معـايير محـد الحقل التور أخـصائى \\
\hline 1 & | دالة & $\begin{array}{l}9 . \wedge r \\
9\end{array}$ & $\vee 1 . \wedge$. & roq & $\wedge \wedge . \vee^{\prime}$ & roo & $\varepsilon \ldots$ & $\varepsilon$ & بين مهام أخصائى الإعـلام التربـوى متعـددة \\
\hline$\varepsilon$ & | دالة*** & r.94 & VO.r. & rVT & vq... & TIT & $7 \ldots$ & 7. & 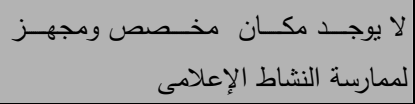 \\
\hline
\end{tabular}




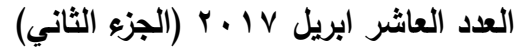

\section{المجلة العلمية لكلية التربية النوعية}

\begin{tabular}{|c|c|c|c|c|c|c|c|c|c|}
\hline$r$ & | دالة**** & $\begin{array}{l}11.71 \\
r\end{array}$ & Vq.Y. & ए97 & 19. & ro9 & rv... & rv & لا ينوافر الدعم المادى المطلوب لممارسة \\
\hline 11 & 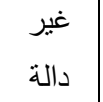 & $\therefore 9$. & $\leqslant 0 . \varepsilon$. & YYV & $\leqslant 0.0$. & INT & $\varepsilon 0 . \ldots$ & $\leqslant 0$ & 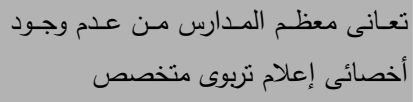 \\
\hline$\wedge$ & | دالة *** & $9 . \leqslant$ ए & $77 .$. & . זד & V... & $\Gamma \cdot \varepsilon$ & r... & r & 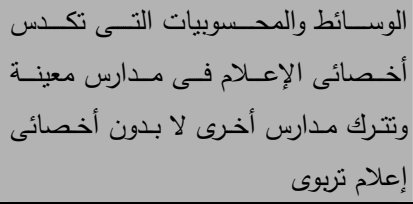 \\
\hline 0 & | دالة_*** & $\begin{array}{l}1 \cdots \\
v\end{array}$ & $V \varepsilon . Y$. & rvi & $\wedge \varepsilon \ldots$ & צחז & ro... & ro & 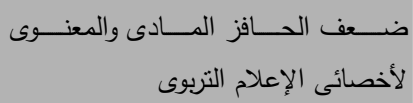 \\
\hline 1. & 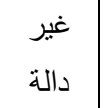 & $\cdot . \leqslant \leqslant \wedge$ & $\varepsilon \vee \ldots$ & rTO & $\leqslant \vee .0$. & 19. & $\leqslant 0 \ldots$ & $\leq 0$ & لالإيوجد اقتناع من المدرسة بقيمة النشاط \\
\hline 9 & 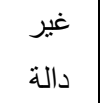 & $\ldots \leqslant 0$ & $0 \leq . Y$. & rVI & $0 \leqslant . Y_{0}$ & YIV & $0 \leq \ldots$ & $0 \leqslant$ & لالمواقع الاككترونية دمـج للنـشاط الإعلامسى مــع \\
\hline$r$ & | دالة*** & $r .070$ & vq... & r9o & AT.ro & rrq & $74 . .$. & 77 & لالإيلامى ارتباط بين تقويم الطالب والنشاط \\
\hline 15 & دالة** & r.07r & rq.r. & 197 & $\varepsilon r . .$. & 171 & r^... & rA & 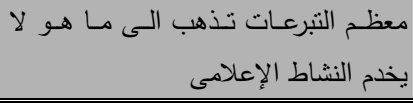 \\
\hline & & & \multicolumn{2}{|c|}{$0 .}$. & \multicolumn{2}{|c|}{$\varepsilon}$. & \multicolumn{2}{|c|}{1.} & جملة من سئلوا \\
\hline
\end{tabular}

تشير بيانات الجدول السابق إلى أهم المعوقات التى تواجـه نشاط الإعلام التربوى من

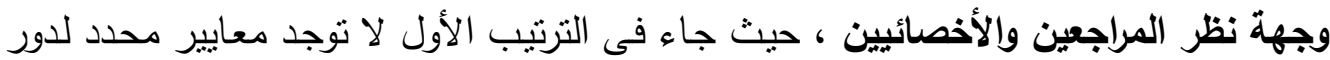

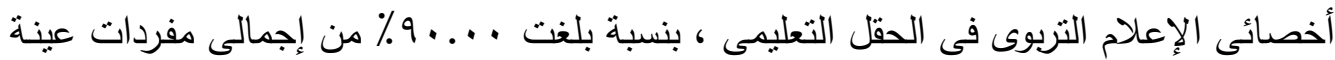

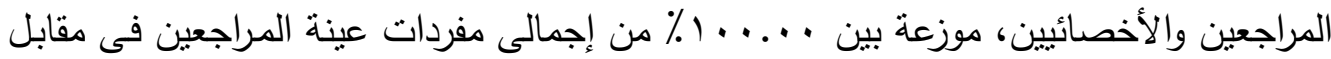
. Av.0. عند مستوى ( ....، فقد بلغت قيمة Z المحسوبة س VY.VT وهى قيمة منبئة بوجود علاقة فارقة بين النسبتين بمستوى ثقة 999 ... وجاء فى الترتيب الثانى لا يتوافر الدعم المادى المطلوب لممارسـة نشاط الإعلام التربوى

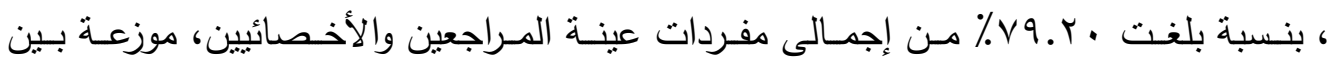

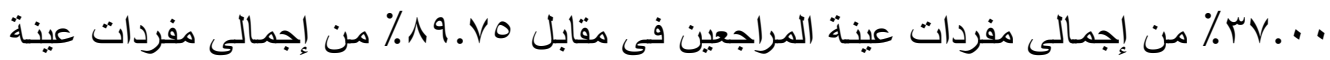

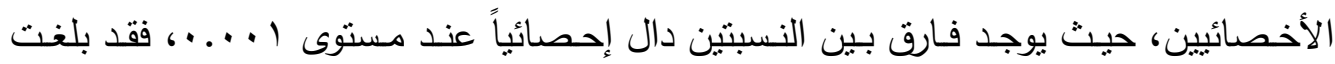




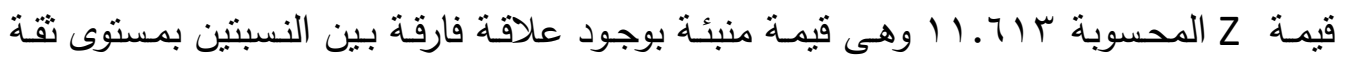

وجاء فى الترتيب الثالث لا يوجد ارتباط بين تقويم الطالب والنشاط الإعلامى ، بنسبة

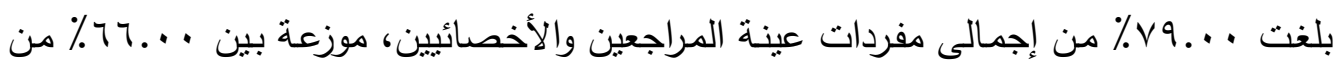

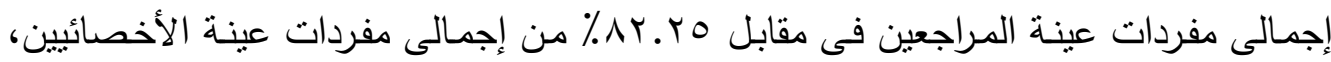

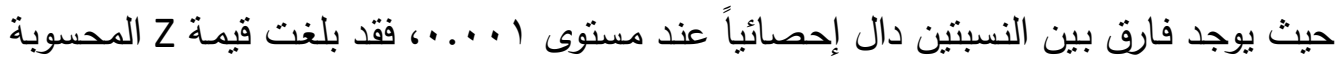
07. 07 وهى قيمة منبئة بوجود علاقة فارقة بين النسبتين بمستوى نقة 999 . ..

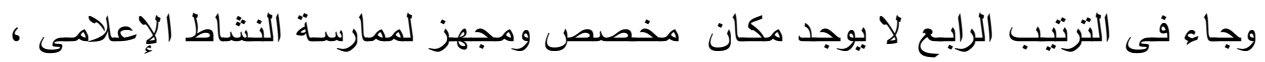

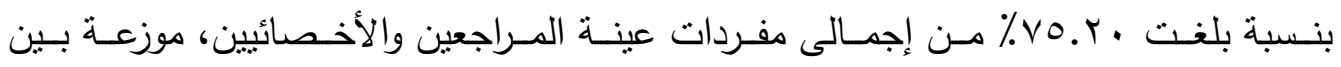

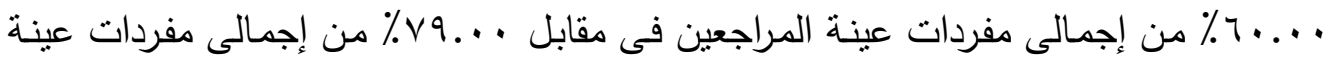

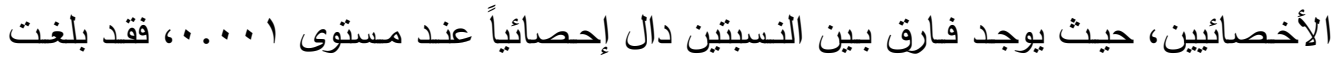

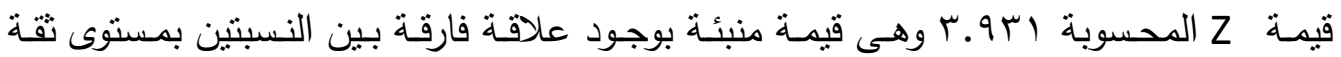

وجاء فى الترتيب الخامس ضعف الحافز المادى والمعنوى لأخصائى الإعلام التربوى ،

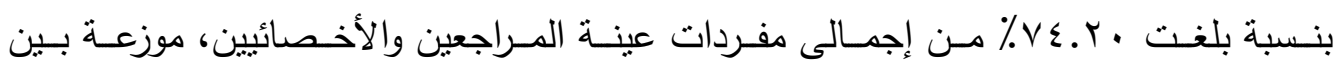

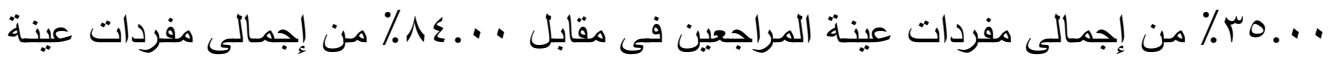

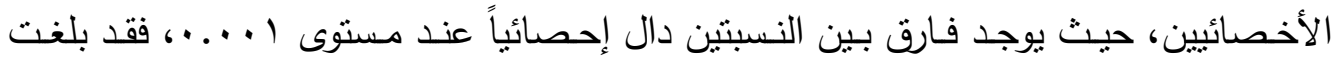

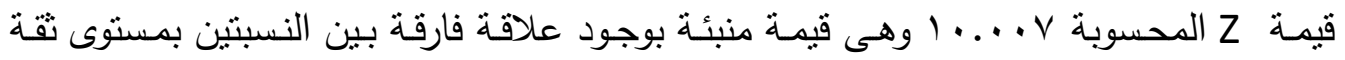

وجاء فى الترتيب السادس مهام أخصائى الإعلام التربوى متعددة بين مسابقات وحصص

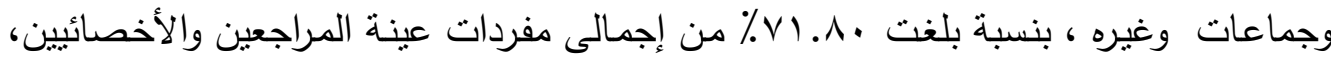

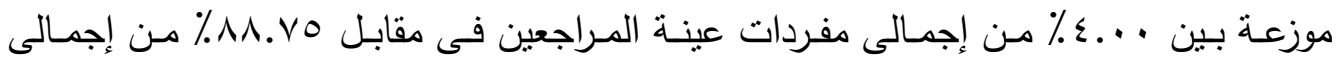
مفردات عينة الأخصائيين، حيث يوجد فارق بين النسبتين دال إحصائياً عند مستوى ل . ....

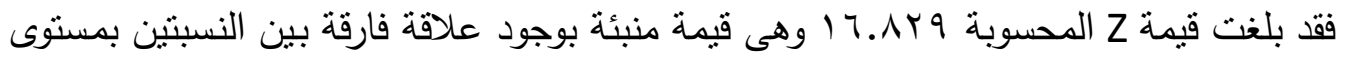

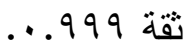

الفرض السادس:- توجد فروق ذات دلالة إحصائية بين عينة الأخصائيين وعينة المراجعين فى تحليد أهم مقترحات حلول المعوقات التى تواجه نشاط الإعلام التريوى. 


\section{جدول رقم (^) - (^)}

أهم مقترحات حلول المعوقات التى تواجه نشاط الإعلام التريوى من وجهة نظر المراجعين

\section{والأخصائيين.}

\begin{tabular}{|c|c|c|c|c|c|c|c|c|c|}
\hline \multirow{2}{*}{ 高: } & \multirow{2}{*}{ الدلالة } & \multirow{2}{*}{ قيمة z } & \multicolumn{2}{|c|}{ الإجمالي } & \multicolumn{2}{|c|}{ الأخصائيين } & \multicolumn{2}{|c|}{ المراجعين } & \multirow{2}{*}{ أهم المقترحات } \\
\hline & & & $\%$ & ك & $\%$ & ك & $\%$ & ك5 & \\
\hline$r$ & دالة & r.ors & $\wedge \vee .7$. & $\varepsilon r \wedge$ & 10... & $r \varepsilon$. & $91 . .$. & 91 & 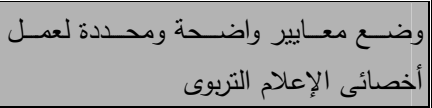 \\
\hline v & | دالة*** & $\begin{array}{l}0 \\
0.1 T\end{array}$ & T^.乏. & $r \leq r$ & VY.O. & rq. & or... & or & 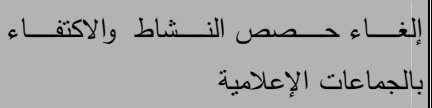 \\
\hline 7 & | دالة *** & $\leqslant .910$ & $79 . \varepsilon$. & $r \leqslant v$ & VT.Vo & $r \cdot v$ & $\varepsilon \ldots$ & $\varepsilon$. & |الإعلام التزبوى دلــل مـن الـوزارة لعــل أخـــائى \\
\hline$r$ & |دالة**** & $\begin{array}{c}1.97 \\
7\end{array}$ & $9 \ldots$ & so. & 19.0. & ron & qr... & 94 & توفير الدعم المادى الملائم لممارسة النشاط \\
\hline 9 & |دالة *** & $0 . .9 r$ & TI.Y. & $r . \tau$ & T7. YO & r7o & $\varepsilon 1 .$. & «1 & 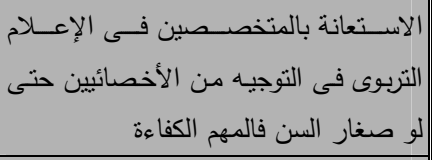 \\
\hline $1 \varepsilon$ & غالة & . TrA & r.. & iNT & rq.vo & 109 & $r \leq \ldots$ & $r \varepsilon$ & 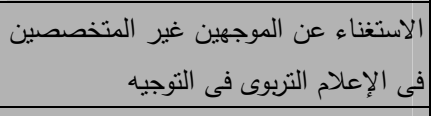 \\
\hline ir & |دالة**** & $\varepsilon .017$ & or... & r. & $\leqslant 9.0$. & 191 & Tr... & Tr & |لاهنتمام بالرسـالة الإعلاميـة بحيث تكون \\
\hline$\wedge$ & مالة د** & $r .099$ & $T V . T$. & צחי & vo... & r.. & r.... & די & كل الإخطار التى تواجهـه للإعلاميين التربويين لمواجهة \\
\hline 1. & |دالة & 0.7r & $7 \varepsilon .7$. & Trt & $77 . \vee 0$ & rTV & $07 . .$. & 07 & الاهنمام بالموهوبين إعلاميا \\
\hline$\varepsilon$ & |دالة**** & $V . Y \cdot \varepsilon$ & V^.乏. & rar & NV.O. & ro. & $\varepsilon r . \ldots$ & $\varepsilon r$ & الإعلام التربوى دعـم مـادى ومعنــوي لأخـــائيين \\
\hline ir & غالة & שVTr & $00 . \varepsilon$. & TVV & $\leqslant 7 . Y_{0}$ & 110 & qr... & 94 & 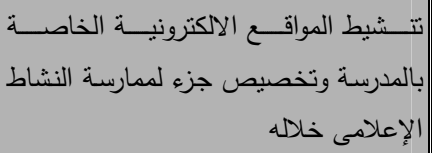 \\
\hline 1 & غيلة & $1.0 \mathrm{rV}$ & qr.T. & $\leq 77$ & 90.10 & rیז & ᄉr... & N & |لتبطريف بأهداف الإعلام التربوى والتمسك للحفاظ على هويته \\
\hline 11 & دالة**** & r.Y97 & ov... & rAo & $77 .$. & YY乏 & r.... & YI & المحلية الإعــام التربـوي بوســائل الإعـلام \\
\hline - & | دالة_** & 11.00 & 79.7. & $r \leq \Lambda$ & vq... & Tו & r.... & rt & 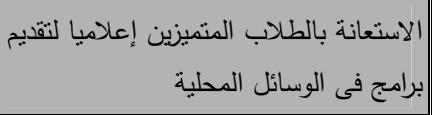 \\
\hline ir & |دالة *** & $\varepsilon .94$. & $00 . \varepsilon$. & TVV & 09.0. & rra & rq... & rq & 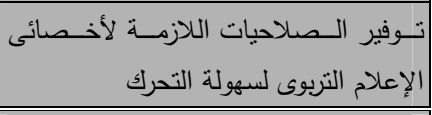 \\
\hline & & & 0 . & & & & 1. & & جملة من سئلوا \\
\hline
\end{tabular}


تشير بيانات الجدول السابق إلى أهم مقترحات حلول المعوقات التى تواجه نشاط الإعلام

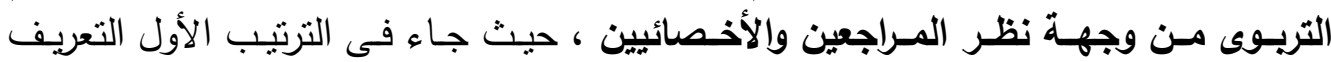

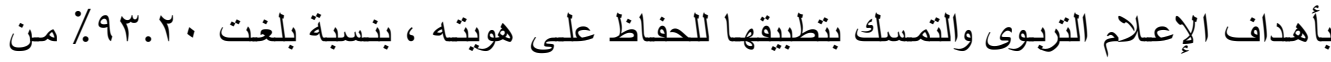

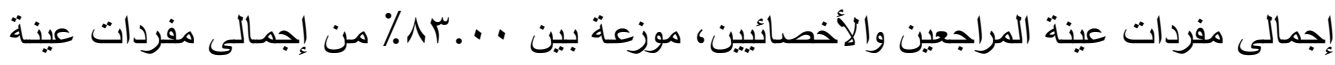

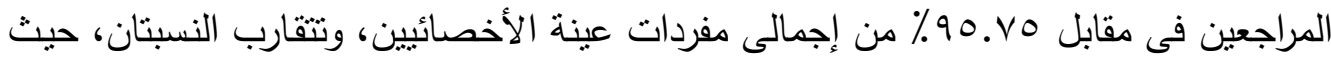

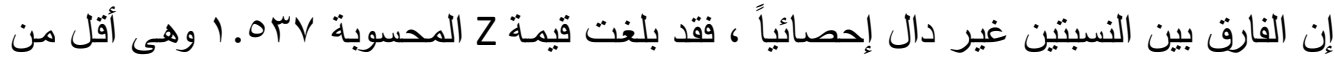
القيمة الجدولية المنبئة بوجود علاقة فارقة بين النسبتين بمستوى ثقة 90 \% \%

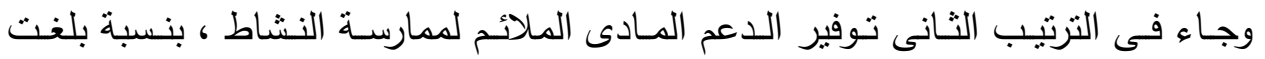

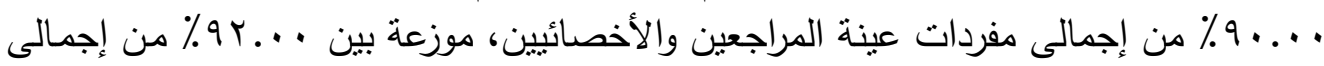

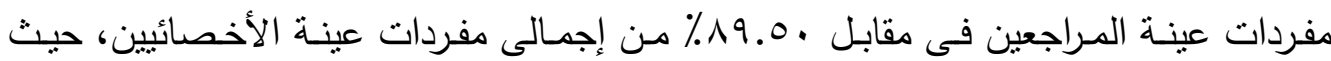

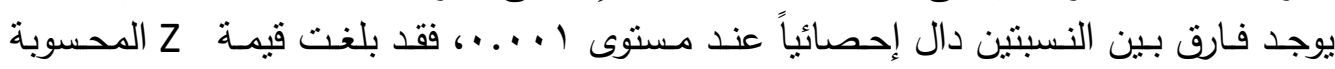

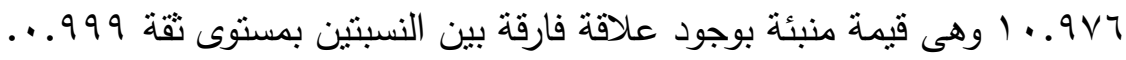

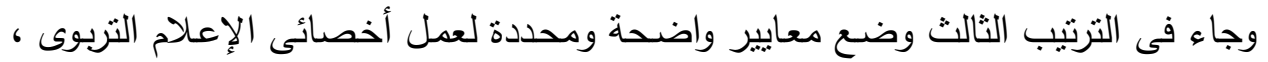

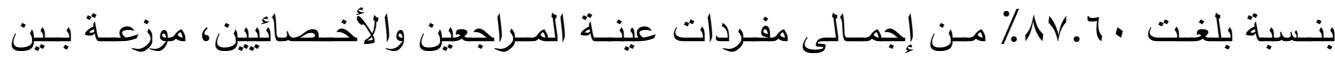

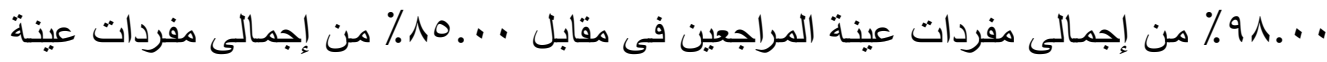

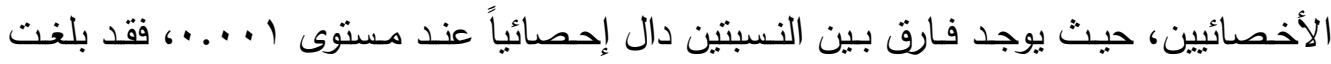

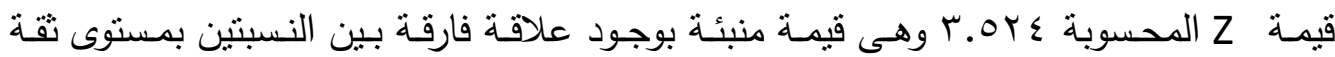

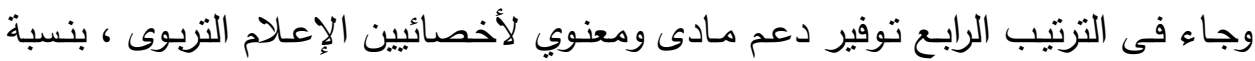

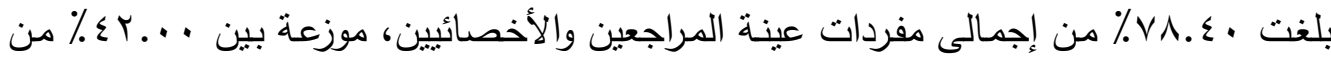

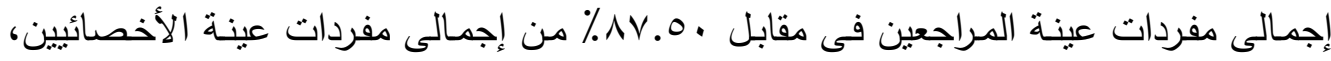

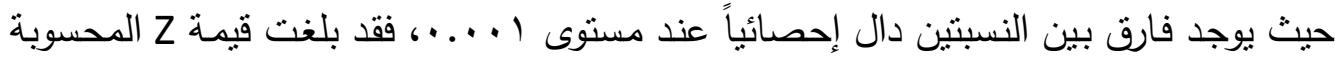

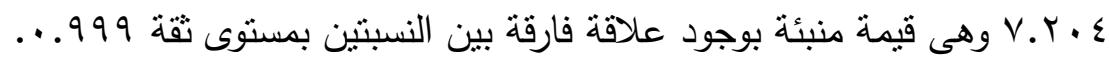

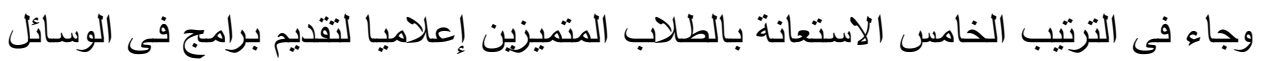

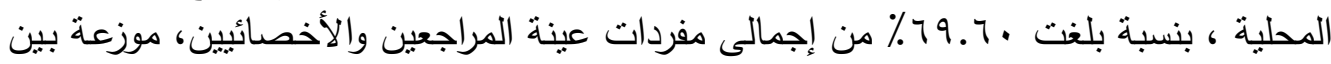

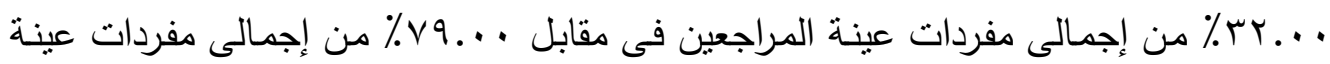

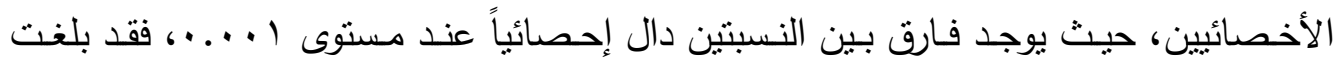

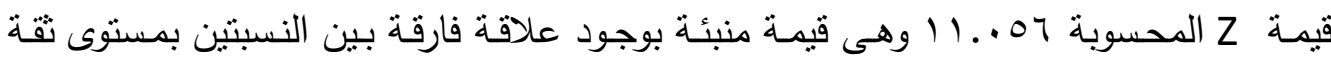
-..999

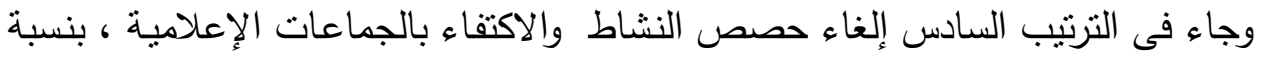

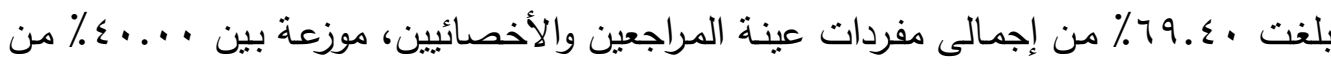

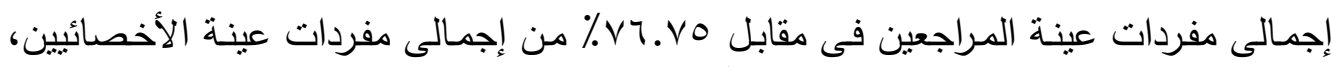

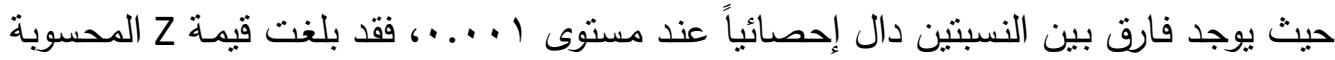

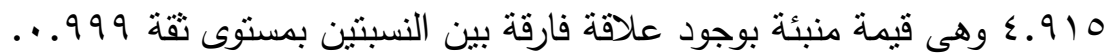


- أهم أسباب القصور فى دور أخصائى الإعلام التربوى من وجهة نظر الأخصائيين وفقا

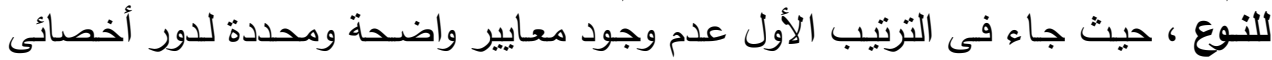

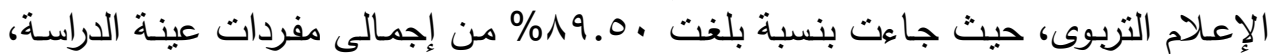

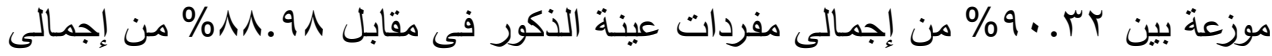

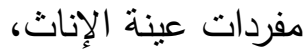

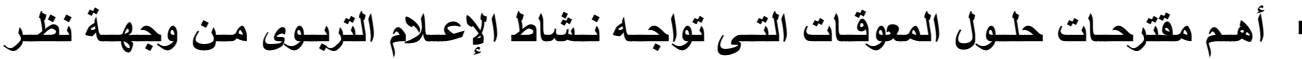
المراجعين والأخصائيين ، حيث جاء في الترتيب الأول التعريف بأهداف الإعلات الإعلام التربوى

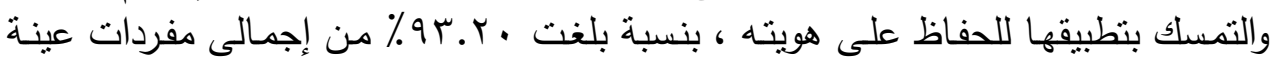

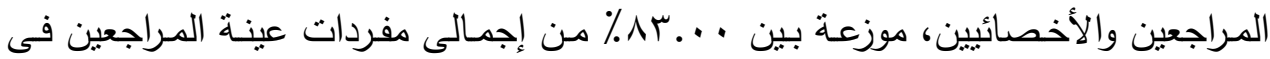

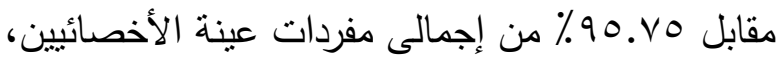

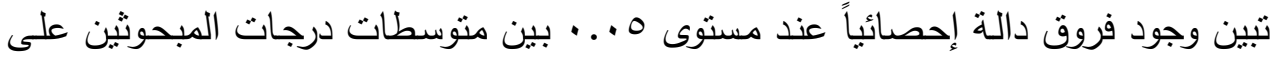

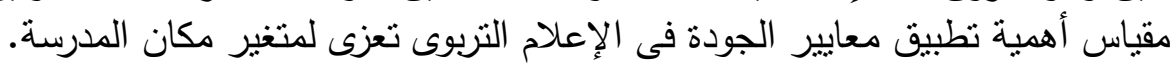

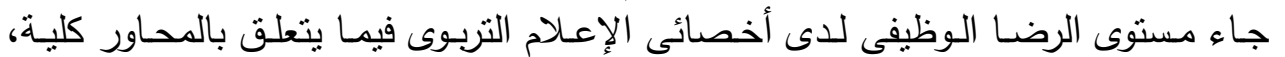

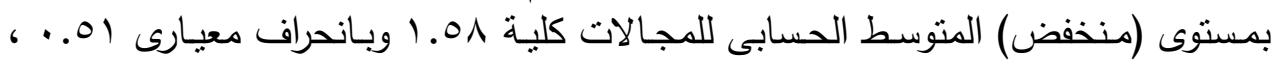

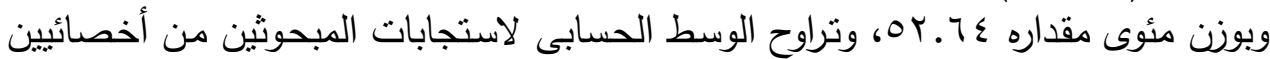

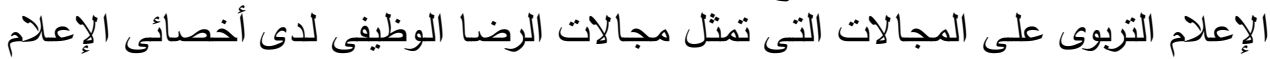

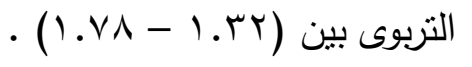

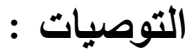

صياغة روئة واضحة ومحددة وطموحة لدور أخصائى الإعلام التربوى من قبل وزارة التربية

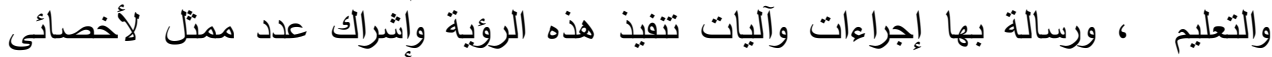

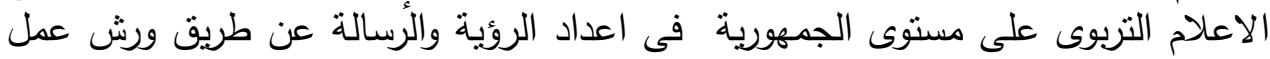

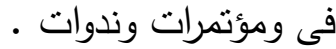
إعنماد الهيئة القومية لضمان اتنوان جودة التعليم والاعتماد لمعايير او ممارسات تتضمنها

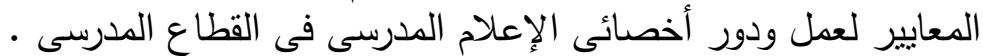

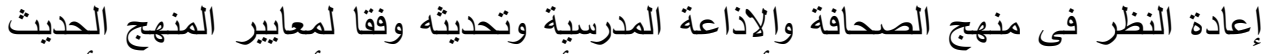

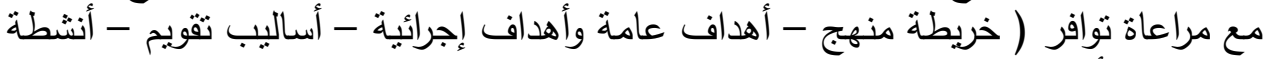

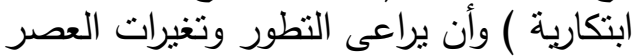

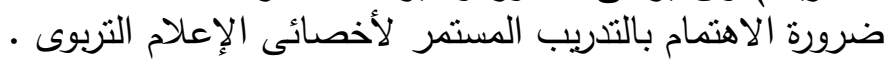

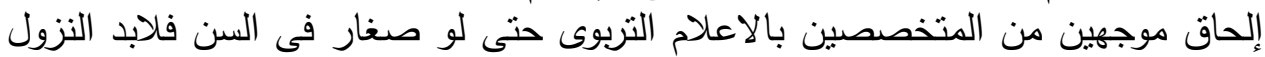

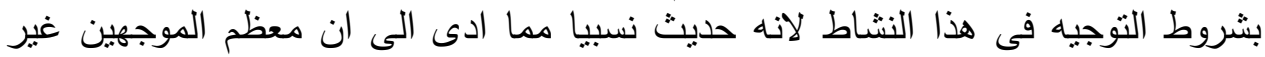

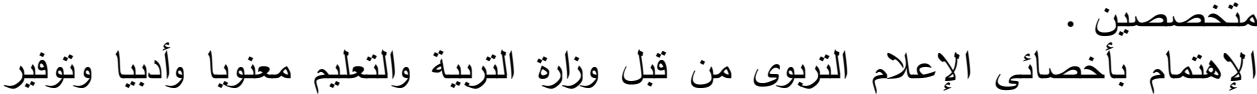

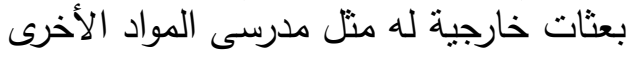
توفير الموارد المادية اللازمة لتتفيذ النشاط من حجرات الإدئ مجهزة ونفقات لتنفيذ المسابقات

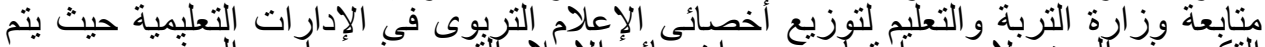

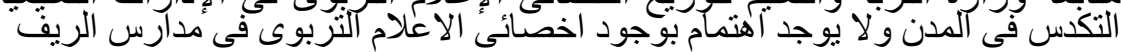


محمد عبدالحميد : البحث العلمى فى الدراسات الإعلامية ، القاهرة ، عالم الكتب ، . ... ب، ص ص

r أحمد عودة (999 (19): القياس و التقويم في العملية التربوية ، القاهرة ، دار الأمل ، الطبعة

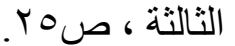

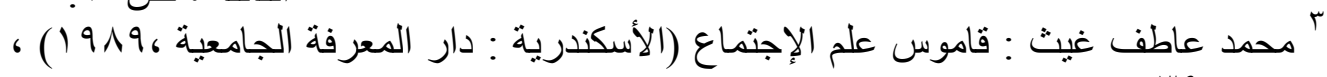

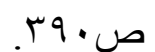
ع صلاح الدين جوهر :مقدمة فى إدارة وتتظيم التعليم (القاهرة : مكتبة عين شمس ، ؛191 ) ) ، ص ص " عبد المنعم فهمى سعد : " تأثيروسائل الإعلام فى العملية التعليمية نحو مشروع حضارى تربوى " ،مجلة التربية المعاصرة ،جماعة إجتماعات التربية برابطة التربية الحديثة ، الجزء

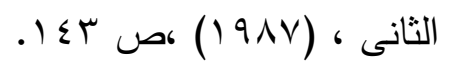
` الهيئة القومية لضمان جودة العليم والإعتماد :الدليل الإسترشادى للمراجع الخارجى ، برنامج الدورة المتقدمة للراجعة الخارجية للمؤسسات التعليم قبل الجامعى (محاضرات غير منشورة

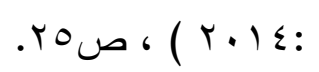

7 Sandra E. Wilson : Student Participation In School Radio Program, Comparative Case Study, in Partial Fulfillment of the Requirements for the Degree Doctor of Philosophy, A Dissertation Submitted to the Temple University Graduate Board, May, 2004 .

^نوف بن دغش بن سعيد القحطاني : الإعلام التربوي ودوره في تفعيل مجالات العمل المدرسي في المملكة العربية السعودية ، رسالة ماجستير ، غير منشورة ، جامعة الملك سعود ،

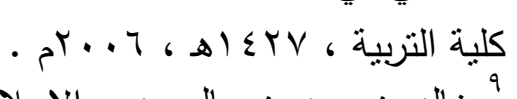

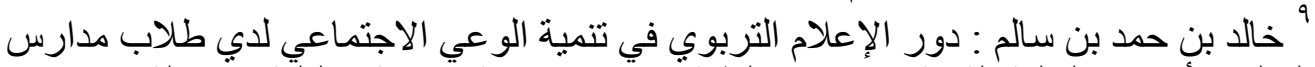

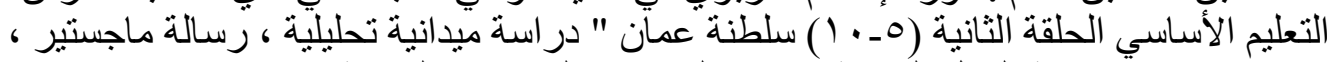

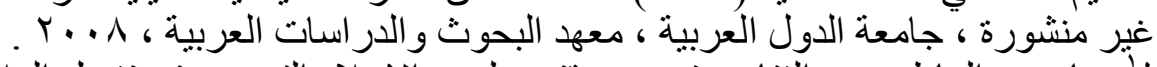

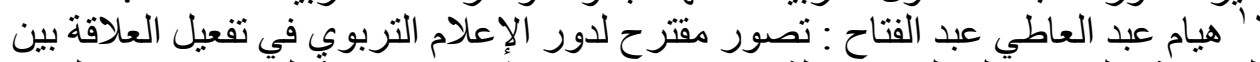

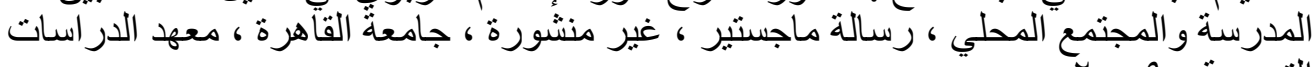

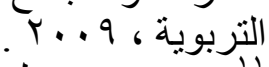

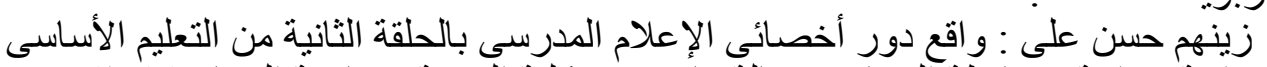

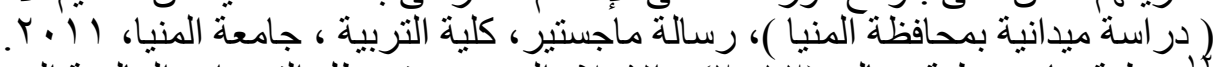

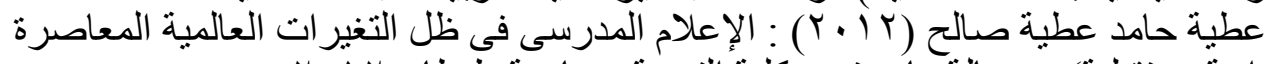

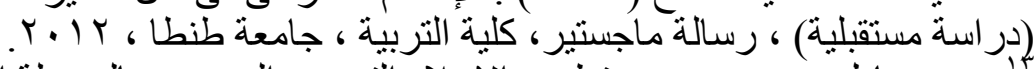

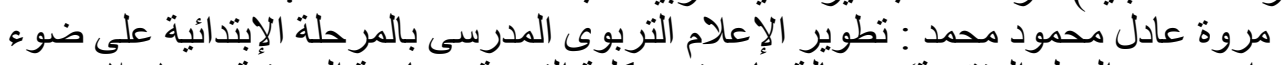

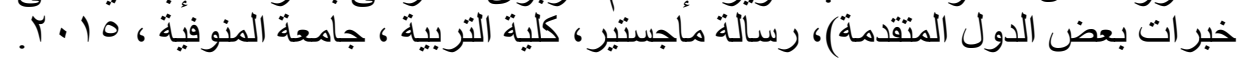




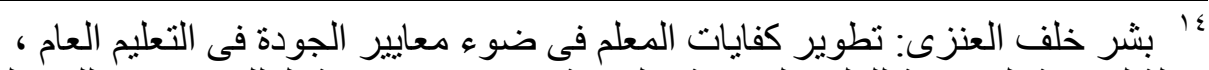

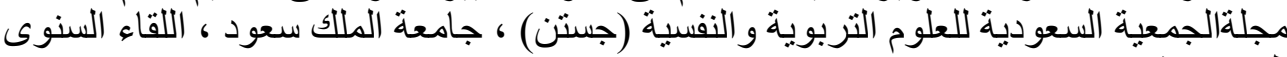

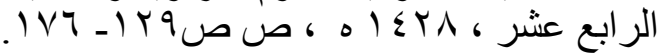

15 Strydom , A-H: Establishing Quality Assurance in The South Africa Context, Quality in Higher Education , Vol.10 No.2, Tylor and Francis Ltd, July . 2009 , p:p 101 :113.

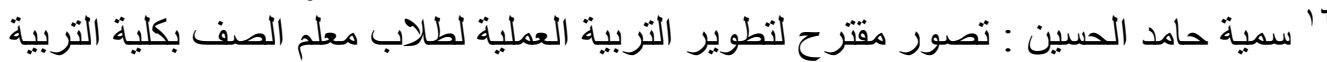

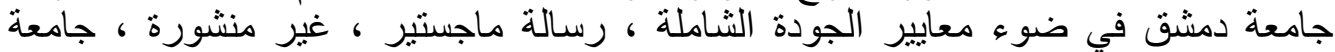

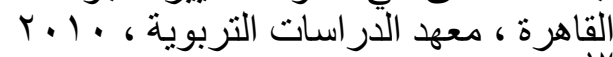

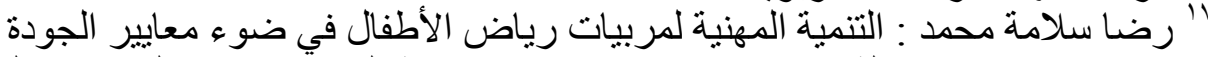

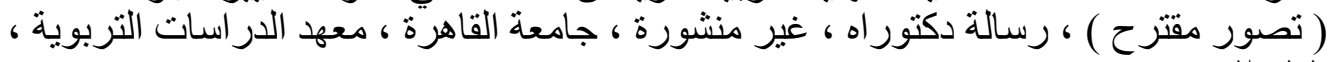

^^ شادي جمال احمد جابر : نطوير مناهج إعداد معلمي المرحلة الإبتدائية في كليات التربية

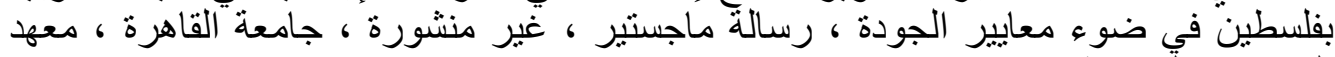

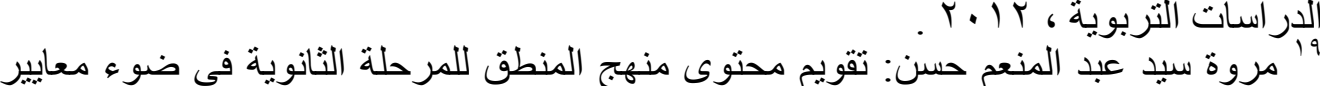

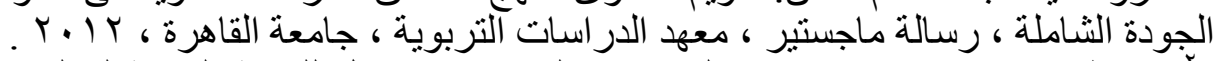

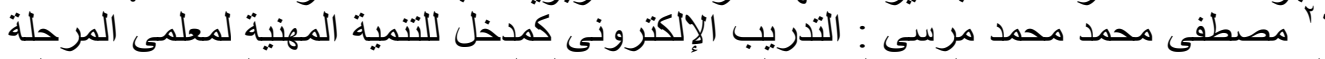

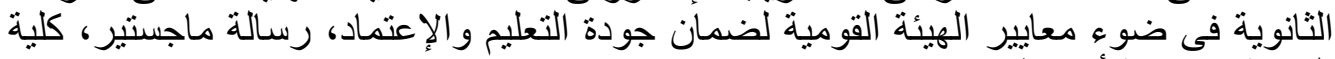

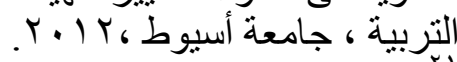

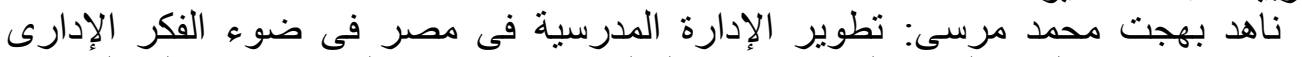

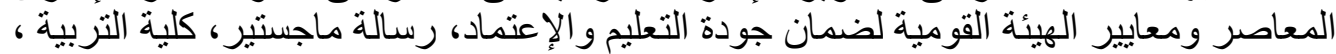

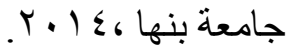

